\title{
MAINSTREAMING BIODIVERSITY AND DEVELOPMENT IN PERU
} Insights and lessons learned

Galina Alova, José Carlos Orihuela, Katia Karousakis
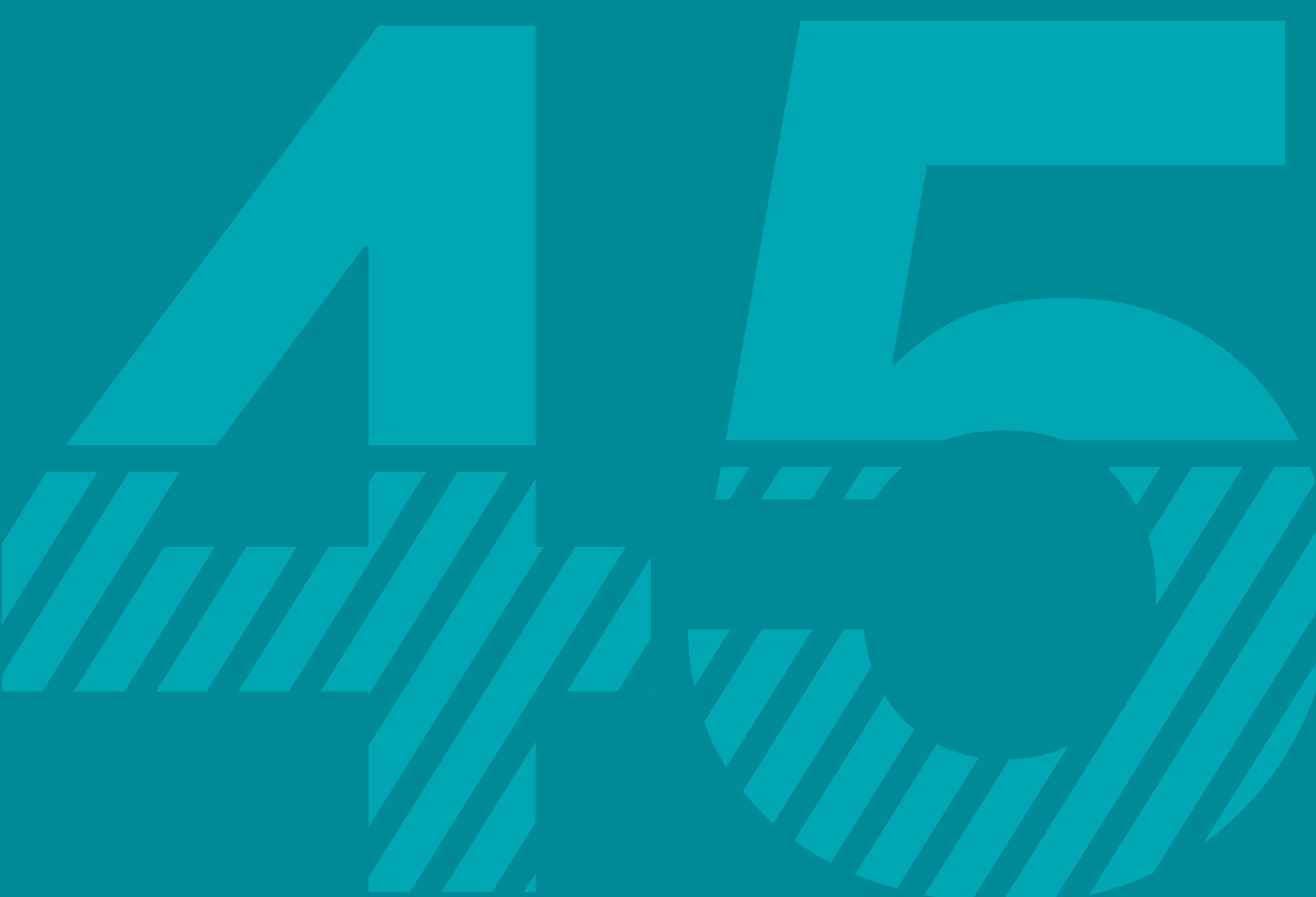

OECD DEVELOPMENT CO-OPERATION WORKING PAPER 45

Authorised for publication by Jorge Moreira da Silva, Director, Development Co-operation Directorate 



\section{OECD Development Co-operation Working Papers}

OECD Working Papers should not be reported as representing the official views of the OECD or of its member countries. The opinions expressed and arguments employed are those of the authors.

Working Papers describe preliminary results or research in progress by the author(s) and are published to stimulate discussion on a broad range of issues on which the OECD works. Comments on the present Working Paper are welcomed and may be sent to Jens.Sedemund@oecd.org, Development Co-operation Directorate, OECD, 2 rue André-Pascal, 75775 Paris Cedex 16, France.

This document and any map included herein are without prejudice to the status of or sovereignty over any territory, to the delimitation of international frontiers and boundaries and to the name of any territory, city or area.

You can copy, download or print OECD content for your own use, and you can include excerpts from OECD publications, databases and multimedia products in your own documents, presentations, blogs, websites and teaching materials, provided that suitable acknowledgement of OECD as source and copyright owner is given. All requests for public or commercial use and translation rights should be submitted to rights@oecd.org. 


\begin{abstract}
Peru relies significantly on its abundant natural capital for economic growth, development and human wellbeing. At the same time, the country's rich terrestrial and marine biodiversity is subject to high pressure as a result of land-use change, overexploitation, industrial development, and illegal mining and logging activities. This paper examines Peru's efforts to integrate biodiversity into decision-making at different levels of the government and in various sectors of the economy. The analysis finds that the Peruvian government recognises the risk that depletion of the country's natural capital may substantially undermine the long-term sustainability of the economy. Significant progress has been made to mainstream biodiversity, for example, through the creation of an enabling institutional and legal framework. However, a number of challenges remain, requiring targeted effective solutions, such as strengthening capacity of the public sector with a focus on the sub-national level, improving the quality and coverage of data to inform biodiversity mainstreaming, and scaling up biodiversity finance including through the use of economic instruments.
\end{abstract}




\section{Acronyms}

AIDESEP

ANA

CAN

CCP

CEPLAN

COMUMA

CONADIB

CONAP

CONCYTEC

DICAPI

ECLAC

EIA

ENBCC

ENDB

FONAM

GEOCATMIN

GIZ

IMARPE

IIAP
Asociación Interétnica de Desarrollo de la Selva PeruanaInterethnic Association for Development of the Peruvian Amazon.

Autoridad Nacional del Agua - National Water Authority

Confederación Nacional Agraria - National Agrarian Confederation

Confederación Campesina del Perú-Peasant Confederation of Peru

Centro Nacional de Planeamiento Estratégico National Centre of Strategic Planning

Comisión Multisectorial de Gestión Ambiental del Medio Marino Costero - Multisectoral Commission for Environmental Management of Coastal Marine Environment

Comisión Nacional de Diversidad Biológica - National Commission on Biological Diversity

Confederación de Nacionalidades Amazónicas de PerúConfederation of Amazonian Nationalities of Peru

Consejo Nacional de Ciencia, Tecnología e Innovación Tecnológica - National Council for Science, Technology and Technological Innovation

Dirección General de Capitanías y Guardacostas -General Direction of Captaincy and Coastguard

Comisión Económica para América Latina y el Caribe -United Nations Economic Commission for Latin America and the Caribbean

Estudio de Impacto Ambiental - Environmental Impact Assessments

Estrategia Nacional de Bosques y Cambio Climatico

Estrategia Nacional de Diversidad Biológica - National Biodiversity Strategy

Fondo Nacional del Ambiente -National Environmental Fund

Sistema de Información Geologico Catastral Minero - Geological Mining Cadastre Information System

Gesellschaft für Internationale Zusammenarbeit -

Instituto del Mar del Perú - Marine Institute of Peru

Instituto de Investigaciones de la Amazonía Peruana - Research Institute of the Peruvian Amazon 
INAIGEM

INDECOPI

INIA

ITP

IUCN

MEF

MEM

MINAGRI

MINAM

MINCETUR

MINCU

MINEDU

MINEM

MRE

MTC

MPFN

NBSAP

OEFA

ONAMIAP

OSINERG

OSINERGMIN

OSINFOR
Instituto Nacional de Investigación en Glaciares y Ecosistemas de Montaña - National Institute for Research on Glaciers and Mountain Ecosystems

Instituto Nacional de Defensa de la Competencia y de la Protección de la Propiedad Intelectual -

National Institute for the Defence of Competition and Protection of Intellectual Property

Instituto Nacional de Innovación Agraria -National Institute of Agrarian Innovation

Instituto Tecnológico de la Producción-Technological Institute of Production

International Union for Conservation of Nature

Ministerio de Economía y Finanzas - Ministry of Economy and Finance

Ministerio de Energía y Minas -Ministry of Energy and Mines

Ministerio de Agricultura y Riego - Ministry of Agriculture and Irrigation

Ministerio del Ambiente - Ministry of Environment

Ministerio de Comercio Exterior y Turismo - Ministry of Foreign Trade and Tourism

Ministerio de Cultura - Ministry of Culture

Ministerio de la Educación - Ministry of Education

Ministerio de Energía y Minas -Ministry of Energy and Mines

Ministerio de Relaciones Exteriores -Ministry of Foreign Affairs

Ministerio de Transportes y Comunicaciones-Ministry of Transport and Communication

Ministerio Público - Fiscalía de la Nación

National Biodiversity Strategy and Action Plan

Organismo de Evaluación y Fiscalización AmbientalEnvironmental Evaluation and Oversight Agency

Organización Nacional de Mujeres Indígenas Andinas y Amazónicas del Perú-National Organization of Andean and Amazonian Indigenous Women of Peru

Organismo Supervisor de la Inversión en Energía -Supervisory Agency of Investment in Energy

Organismo Supervisor de la Inversión en Energía y Minería Supervisory Agency of Investment in Energy and Mining

Organismo de Supervisión de los Recursos ForestalesSupervisory Agency Forest Resources 
PCM

PIP

PNCBMCC

PNSE

PRODUCE

PROFONANPE

PTPA

REDD

RETC

SANIPES

SECO

SEIA

SENACE

SENASA

SERFOR

SERNANP

SERVIR

SIAMAZONIA

SIGERSOL

SINADA

SINANPE
Presidencia del Consejo de Ministros -Ministers Council Presidency

Proyecto de Inversión Pública -Public Investment Project

Programa Nacional de Conservación de Bosques

para la Mitigación del Cambio Climático - National Forest Conservation Programme for the Mitigation of Climate Change

Plataforma Nacional de Servicios Ecosistémicos - National Platform for Ecosystem Services

Ministerio de la Producción -Ministry of Production

Fondo Nacional para las Áreas Naturales Protegidas por el Estado

-National Fund for Natural Areas Protected by the State

Peru Trade Promotion Agreement

Reducing Emissions from Deforestation and Forest Degradation

Registro de Emisiones y Transferencia de Contaminantes Registry of Pollutant Emissions and Transfer

Organismo Nacional de Sanidad Pesquera -National Agency of Fisheries Health Service

Swiss State Secretariat for Economic Affairs

Sistema Nacional de Evaluación de Impacto Ambiental-National System for Evaluation of Environmental Impact

Servicio Nacional de Certificaciones para las Inversiones Sostenibles -National Service of Certification for Sustainable Investment

Servicio Nacional de Sanidad Agraria del Perú -National Agricultural Health Service of Peru

Servicio Nacional Forestal y de Fauna Silvestre -National Forestry and Wildlife Service

Servicio Nacional de Áreas Naturales Protegidas por el Estado National Service of Protected Natural Areas by the State

Autoridad Nacional del Servicio Civil -National Civil Service Authority

Sistema de información de la diversidad biológica y ambiental de la amazonía peruana - Information System on Biological and Environmental Diversity of the Peruvian Amazon

Sistema de Informacion para la gestion de los Residuos Sólidos Information System for Solid Waste Management

Servicio Nacional de Denuncias Ambiantales - National Environmental Complaints Information Service

Sistema Nacional de Áreas Naturales Protegidas -National System of Protected Natural Areas 
SINEFA

SINIA

SNGRH

SNIRH

SNIP

SUNAT
Sistema Nacional de Evaluación y Fiscalización Ambiental National System of Enviromental Evaluation and Control

Sistema Nacional de Información Ambiental - National System of Environmental Information

Sistema Nacional de Gestión de Recursos Hídricos -National System of Water Resources Management

Sistema Nacional de Información en Recursos Hídricos - National Information System of Water Resources

Sistema Nacional de Inversión Pública -National System of Public Investment

Superintendencia Nacional de Aduanas y de Administración Tributaria -National Superintendency of Customs and Tax Administration 


\section{Acknowledgements}

This paper was authored by Galina Alova (Development Co-operation Directorate (DCD)), José Carlos Orihuela (Pontifical Catholic University of Peru) and Katia Karousakis (Environment Directorate (ENV)). It constitutes a case study, as part of the OECD joint project "Mainstreaming Biodiversity for Sustainable Development", under the Working Party on Biodiversity, Water and Ecosystems (WPBWE) of the Environment Policy Committee, and the Network on Environment and Development Co-operation (ENVIRONET) of the Development Assistance Committee. Comments received from the delegates of the WPBWE and ENVIRONET are gratefully acknowledged. The OECD would like to thank the European Commission and the Federal Ministry for Economic Cooperation and Development, Germany (BMZ), through the German Gesellschaft für Internationale Zusammenarbeit (GIZ) for the financial support in undertaking this project. The views expressed herein can in no way be taken to reflect the official opinion of the European Union, BMZ or GIZ.

The authors would like to thank the Ministry of Environment of Peru for their collaboration and assistance in co-ordinating the OECD mission to Lima, Peru in June 2016. In particular, thanks are owed to Gabriel Quijandría, former Vice Minister for Strategic Development of Natural Resources; José Álvarez Alonso, Director General of Biodiversity; and Miriam Mercedes Cerdán Quiliano, former Director General of Biodiversity; and their team: Rosemarie Avila and José Carrasco. The study also benefitted from comments by Roxana Solis Ortiz and Maria Luisa del Rio Mispireta. Silke Spohn, Willian Fernando León Morales and Alejandra Muñoz Gonzáles at the GIZ Peru also provided support to the OECD team in preparing the mission.

The authors are also grateful to the representatives from the Ministry of Economy and Finance; National Centre of Strategic Planning; National Forestry and Wildlife Service, Ministry of Production; Ministry of Energy and Mining; Ministry of Foreign Trade and Tourism; and Ministry of Transport and Communications; as well as from academia, civil society, private sector, and development co-operation institutions (GIZ, World Bank, InterAmerican Development Bank, United Nations Development Programme, United States Agency for International Development, Japan International Cooperation Agency, and Food and Agriculture Organisation of the United Nations) for their time, participation in the interviews and valuable insights provided.

Review and comments from the following OECD colleagues are also recognised with thanks: Simon Buckle (ENV), Jan Corfee Morlot (DCD), Liwayway Adkins (DCD), Naeeda Crishna Morgado (DCD) and Roger Martini (Trade and Agriculture Directorate).
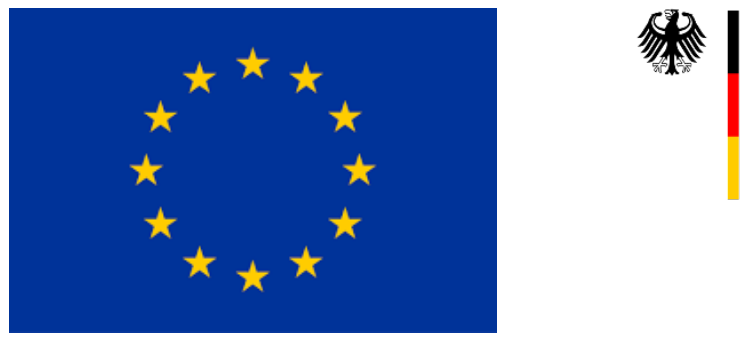

Federal Ministry

for Economic Cooperation

and Development 


\section{TABLE OF CONTENTS}

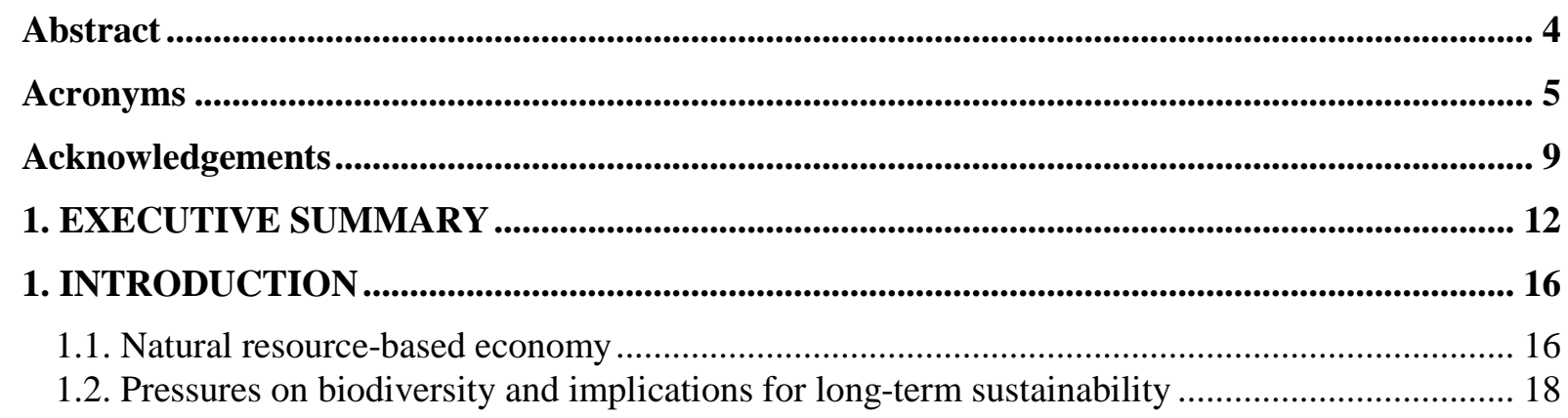

2. MAINSTREAMING BIODIVERSITY AT NATIONAL LEVEL ............................................... 20

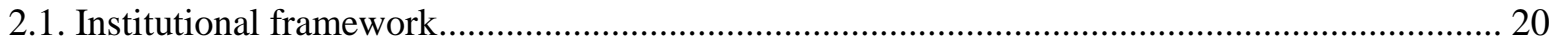

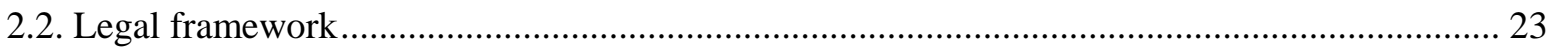

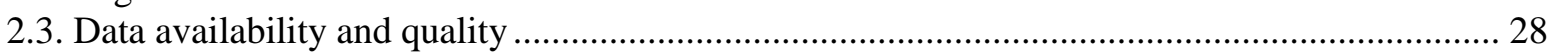

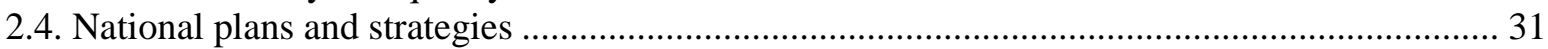

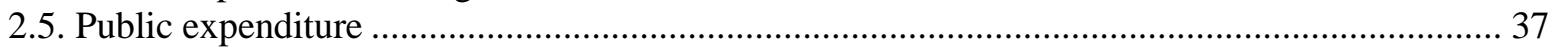

3. MAINSTREAMING BIODIVERSITY AT SECTOR LEVEL ................................................ 40

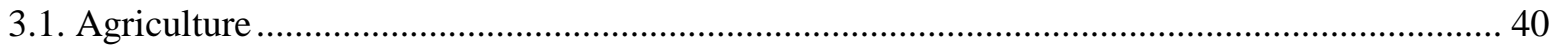

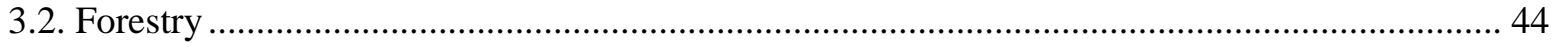

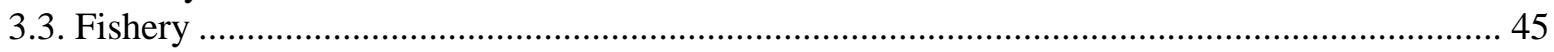

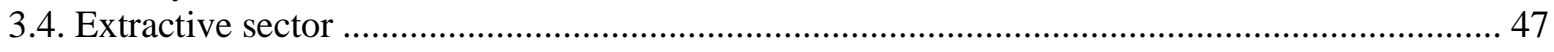

4. DEVELOPMENT CO-OPERATION SUPPORT TO MAINSTREAMING ............................. 54

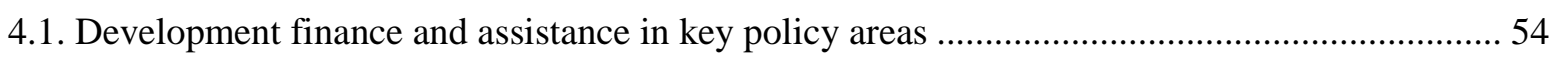

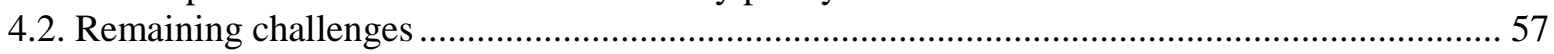

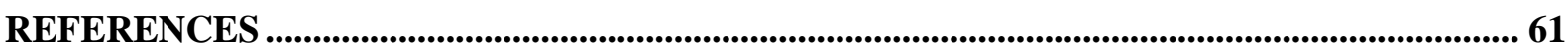

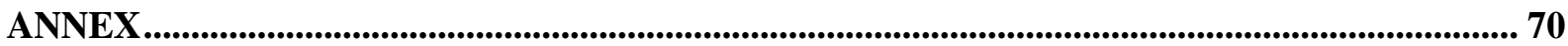

\section{Tables}

Table 2.1. Biodiversity-relevant information platforms within National System of Environmental

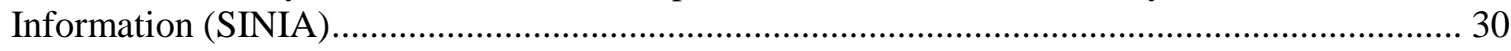

Table 2.2. Institutions responsible for implementation of National Biodiversity Targets .................... 35

Figures

Figure 1.1. Cumulative deforestation in Peru by region, 2001-2015 ................................................. 18

Figure 2.1. Environmental institutional framework in Peru ................................................................ 21

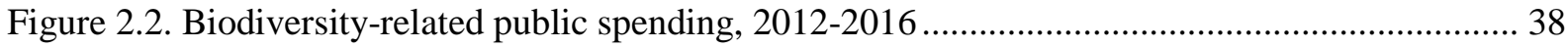

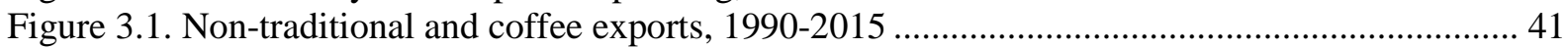

Figure 3.2. Increase in cultivated area of cacao, coffee and palm oil, 1990-2015 …........................... 43

Figure 3.3. Increase in exports of traditional and non-traditional fish products, 1990-2015 ................ 46 
Figure 3.4. Mining and hydrocarbons as percentage of exports and GDP, 1950-2015 ........................ 48

Figure 3.5. Mining industry's environmental fines, 2007-2015 ....................................................... 51

Figure 3.6. Mining and hydrocarbons as a share of fiscal revenues, 2000-2014................................. 52

Figure 3.7. Sub-national transfers of corporate income tax, cumulative 2005-2014............................. 53

Figure 4.1. Focus on environment-related objectives in bilateral ODA in Peru ................................... 54

Figure 4.2. Bilateral biodiversity-related ODA in Peru, 2006-2015 .................................................. 55

Figure 4.3. Mainstreaming in top sectors receiving biodiversity-related ODA in Peru ........................ 60

\section{Boxes}

Box 1. Public sector capacity challenges and turnover ....................................................................... 23

Box 2. History and reform of Environmental Impact Assessment in Peru ............................................ 25

Box 3. Indigenous Peoples in the management of the Peruvian Amazon .............................................. 27

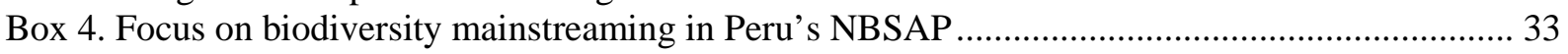

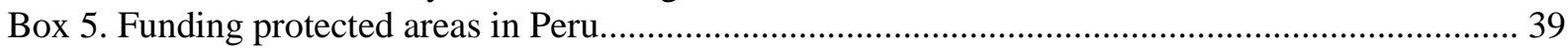

Box 6. Palm oil plantations deforest primary forest and violate the rights of indigenous communities 42

Box 7. Illicit gold mining poses a major risk to biodiversity and erodes government revenues ........... 49

Box 8. USAID comprehensive biodiversity policy package guides mainstreaming in practice ........... 60 


\section{Executive summary}

Peru relies significantly on its abundant natural capital for economic growth, development and human well-being. At the same time, the country's rich terrestrial and marine biodiversity is subject to high pressure as a result of land-use change, overexploitation, industrial development, and illegal mining and logging activities. Over the past years, Peru has experienced substantial deforestation and forest degradation, which could create high costs to the economy in foregone ecosystem services. Marine ecosystems are also under severe pressure from overfishing and pollution.

The Peruvian government recognises the risk that persistent depletion of the country's natural capital may substantially undermine the long-term sustainability of the economy and the well-being of its people. Progress has been made in a number of areas to integrate biodiversity into decision-making at different levels of the government and in various sectors of the economy. However, a number of challenges remain, requiring targeted effective solutions.

\section{Peru has made important strides that should help facilitate biodiversity mainstreaming}

\section{Creation of an enabling institutional and legal framework}

The institutional framework relevant for sustainable management of biodiversity has undergone substantial transformation over the past decade, starting with the creation of the Ministry of Environment (MINAM) in 2008 and its auxiliary agencies. This led to an extensive consolidation of responsibilities for environmental issues from sector authorities. An important advancement in this regard is the transfer of control over enforcement of environmental legislation to the agencies under the MINAM's authority - the Environmental Assessment and Oversight Agency (OEFA) and the National Service of Certification for Sustainable Investment (SENACE).

In parallel, Peru also achieved a significant progress in developing a legal framework to support the implementation of biodiversity-focused policies. Amongst the key recent milestones is the Forestry and Wildlife Law (2011) and its four regulations which provide a framework for sustainable forest management, and the Previous Consultation Law (2011) that makes it mandatory to conduct consultations with indigenous peoples prior to developing new legislation that may affect their territories and rights. Another major development is the Law on Compensation Mechanisms for Ecosystem Services (2014) that channels public and private financial flows to promote Payment for Ecosystem Services (PES) schemes.

\section{Signs of emerging policy coherence}

Peru has also achieved a degree of policy coherence across key national strategies which are instrumental to reciprocal mainstreaming. The National Biodiversity Strategy and Action Plan (NBSAP) recognises the importance of biodiversity for development. It has a clear implementation matrix, comprising specific mainstreaming-related national targets, actions and indicators. At the same time, biodiversity considerations are reflected in Peru 2021 Bicentennial Plan - a long-term national development agenda, and the National Productive Diversification Plan (PNDP) which recognises the importance of a more effective use of natural resources, particularly with a focus on sustainable development of 
the forestry sector, as a driver for the country's economic diversification and sustainable growth.

\section{Incipient efforts in sector mainstreaming}

Agriculture, fishing, and mining and oil are important sectors for the Peruvian economy, cumulatively accounting for $68 \%$ of exports and 18\% of GDP in 2015, based on the data from the Central Reserve Bank of Peru. At the same time, these sectors exert significant pressure on biodiversity through deforestation, forest degradation and overfishing. Efforts are emerging to more sustainably use biodiversity within sector activities. These include promoting sustainable biodiversity-friendly agro-forestry practices, and incentives to conserve agro-biodiversity by local communities, particularly indigenous peoples who hold extensive knowledge of the use of genetic resources. The effectiveness of these policy efforts in practice is yet to be tested. Following the collapse of the anchovy industry, the introduction of individual vessel quotas to recover anchovy population has been an important policy achievement. Moreover, the transfer of the responsibilities for evaluating Environmental Impact Assessments (EIAs) of large-scale mining and other projects from sector authorities to SENACE is expected to improve the independence of these evaluations. The government's commitment to develop a formal sustainably managed forestry sector is also an important step, particularly for combatting illegal logging.

\section{Productive collaboration with development partners}

Development co-operation actors - bilateral and multilateral - have supported the government to achieve several milestones that have shaped the national institutional and legal landscape for biodiversity mainstreaming, including the creation of MINAM and the formulation of the National Action Plan for the Environment 2010-2021 (PLANAA). Development partners also assisted the government in implementing policy instruments, providing financing, and technical assistance. Efforts to improve inter-ministerial coordination and private sector engagement also benefited from development co-operation assistance.

This is also reflected by an improvement in the focus on biodiversity within Official Development Assistance (ODA) to Peru. Biodiversity-related bilateral ODA has more than doubled over the past decade. Donors increasingly harness the synergies between biodiversity conservation and sustainable use, and other development activities.

\section{Several areas impede implementation and require continued effort to improve mainstreaming}

While Peru has made progress in sustainably managing biodiversity in certain areas, there are several challenges that need to be addressed:

\section{Formalise land tenure and reduce the large size of the informal sector}

The lack of legal land tenure and the large size of the informal sector in agriculture, mining and forestry often lead to unregulated land-use changes which in turn may trigger biodiversity loss. A large share of forest area is unclassified falling outside any legal and administrative control, while the vast majority of farmers have no land title. The lack of land titling often results in farming activities taking place in areas with scarce water resources or areas which should be subject to forest and watershed protection. At the same time illicit gold mining poses a major risk to biodiversity through deforestation, and forest and land degradation. Formalising land tenure rights in a way that respects the interests of 
indigenous peoples and local communities, and reduces the spread of illegal uncontrolled activities, is essential for effective mainstreaming.

\section{Strengthen capacity of the public sector with a focus on the sub-national level}

The effectiveness of an emerging enabling institutional framework for mainstreaming is significantly undermined by the limited technical and administrative capacity of the Peru's public service, particularly at the sub-national level, aggravated by high personnel turnover. The magnitude of the challenge has become particularly evident in the course of decentralisation, when sub-national governments received substantial new responsibilities, whilst their capacity continued to lag behind. Recognising these challenges, the government has launched large-scale civil service reform. The effectiveness of the reform will largely determine Peru's ability to effectuate successful mainstreaming in the future.

\section{Improve the quality and coverage of data to inform biodiversity mainstreaming}

While Peru has a substantial history of biodiversity-related data collection and management, gaps in its current quality and coverage impede policy planning and implementation. In particular, the often fragmented and scattered nature of data makes it difficult to build a robust case for biodiversity mainstreaming across the economy. To address this challenge, efforts are underway to improve the country's data collection and management capacity, including through the development of an integrated national environmental information system (SINIA). The system co-ordinates data collection from several institutions, in order to build on-line platforms that cover a number of crucial areas to inform users and policymakers in the area of biodiversity mainstreaming.

\section{Scale up finance for biodiversity and the use of economic instruments}

The government has made commendable steps towards the development of a transparent and results-based budgeting system. However, this reveals that prioritisation of biodiversity within government budgets remains limited, creating a large funding deficit. To an extent, the low level of public investment can be explained by the lack of implementable projects, and a degree of disconnection between policy planning and public investment decisions. Therefore, even if biodiversity might be well mainstreamed in national strategies, this may not always translate into implementation. The government has recently made efforts to improve guidance on public investment in biodiversity and ecosystem services.

Furthermore, Peru relies predominantly on command-and-control approaches to conserve and sustainably use biodiversity, while the adoption of economic instruments, which can also help to generate revenue, is limited. There is scope to re-assess the use of government revenues generated by the extractive sector, a minor share of which are required to be reinvested at sub-national level into the communities and indigenous peoples affected by environmental damage or land-related disputes.

\section{Enhance mainstreaming within ODA to sectors that tend to affect biodiversity}

There is a limited degree of mainstreaming within ODA to some sectors that have a significant impact on biodiversity, such as mining and agriculture. It is important to continue to harness the synergies between biodiversity and the development projects in other sectors to ensure that, at a minimum, they do not support activities harmful to biodiversity.

\section{Ensure continuity of impact achieved by development co-operation}


There is a need to ensure that the positive results achieved by development co-operation programmes are preserved beyond the lifetime of specific projects, by improving government buy-in, including through sufficient budget allocation to biodiversity-related activities. 


\section{Introduction}

Peru is one of the most megadiverse countries in the world (MINAM, 2012), as well as a leading Latin American economy, supported to a significant extent by its abundant natural resources. At the same time, the country's rich terrestrial and marine biodiversity is subject to high pressure as a result of land-use change, overexploitation, industrial development, and illegal mining and logging activities, undermining the long-term sustainability of the Peruvian economy.

This report examines approaches adopted by Peru to reconcile biodiversity conservation and sustainable use considerations with its wider socio-economic development objectives at the national and sector level, i.e. mainstreaming biodiversity across the economy and society, and the role of development co-operation in supporting this process. ${ }^{1}$

The aim of the report is to derive good practices which can be scaled up across the whole economy to advance mainstreaming, and lessons learned which can help find solutions to remaining challenges. These insights could be relevant to other countries prioritising policy coherence and a cross-cutting approach to managing natural capital.

The report is structured as follows: Chapter 1 provides an overview of key economic developments in Peru and associated challenges for biodiversity. Chapter 2 examines the state-of-play of biodiversity mainstreaming at the national level, with respect to institutional and legal frameworks, data and information systems, government budget and cross-sectorial national strategies and policies. Chapter 3 examines the approaches and policy instruments that have been adopted to mainstream biodiversity in the following sectors: agriculture, forestry, fisheries and mining. Chapter 4 focuses on the role of development co-operation in supporting biodiversity mainstreaming.

\subsection{Natural resource-based economy}

Over the past decade, the Peruvian economy exhibited strong performance, growing annually on average by nearly 5.5\% between 2007 and 2016, in the context of relatively low inflation of 3.6\% (BCRP, 2017; World Bank, 2017a). This is a major change from Peru's recent history of economic collapse and hyperinflation in the late 1980s. As a result of the steady growth, Peru transitioned to an upper middle-income economy in 2008 (OECD, 2016a), with the gross national income (GNI) per capita amounting to USD 6130 , and GDP totalling USD 190 billion in 2015 (World Bank, 2017a). Along with overall economic growth, there has been also a significant decline in national poverty levels, from $58.7 \%$ in 2004 to $20.7 \%$ in $2016 .^{2}$

\section{Economic growth is supported by natural resource exports}

The growth of the Peruvian economy has relied heavily on natural resources, particularly the exports of minerals, such as copper, gold, lead and zinc (OECD, 2016a). In 2015, the extractives sector, comprising oil, gas and minerals, accounted for $12 \%$ of GDP and for

\footnotetext{
${ }^{1}$ The report also draws on the insights from bilateral and round-table discussions held by the OECD study team in Lima, with the support from the Ministry of Environment (MINAM) in June 2016. These meetings brought together the main stakeholders from the government, academia, private sector and development co-operation. A full list of stakeholders consulted is provided in Annex.

${ }^{2}$ World Bank's poverty headcount ratio at national poverty lines (\% of population)
} 
over $60 \%$ of national exports. The agriculture, forestry and fisheries sectors cumulatively contribute 6\% to GDP (BCRP, 2017). There has also been an increase in recent years in non-traditional exports particularly in the agriculture and fisheries sectors, in an attempt to diversify the economy away from the commodity exports reliance (OECD, 2016a). Exports of non-traditional agriculture and fisheries sectors reached $15.5 \%$ in 2015, compared to traditional exports of 6.3\% (BCRP, 2017).

Despite these positive trends, there are several cross-cutting and inter-related challenges for future sustainable economic growth and development of Peru (OECD, 2015). First, despite the significant reduction in poverty levels, inequality remains high with a Gini coefficient of 44.1\% (World Bank, 2017b), and regional disparity levels above the OECD average (OECD, 2015). Peru's economic activity and political power is concentrated in the capital Lima, where a quarter of the total population lives, while poverty levels are the highest in remote rural locations. For instance, the national poverty rate in Lima metropolitan area was $11 \%$ in 2015 , while in the rest of the country it was $26.8 \%$, and in rural areas it reached 45.2\% (ENAHO, 2015). Second, several key sectors, such as agriculture, have low labour productivity (OECD, 2016a; OECD, 2015). Third, the Peruvian economy is characterised by high levels of informality, estimated at $30-45 \%$ of GDP (Machado 2014), with roughly half of workers employed informally ${ }^{3}$ (OECD, 2015). These socio-economic challenges have significant environmental implications, including for biodiversity and ecosystem services.

\section{Peru is abundant in biodiversity on which many people depend for their livelihoods}

Peru hosts $10 \%$ of world species and 84 of 117 global life zones, ranking first for its fish, second for bird, fourth for amphibian and fifth for mammal diversity (MINAM, 2012). The country encompasses large extensions of the Tropical Andes Biodiversity Hotspot, two natural World Heritage sites, two mixed natural-cultural World Heritage sites and 13 Ramsar sites (USAID, 2014a). The country also features 27 types of climate, and three physiographic provinces, with the Andean Mountains (Sierra) stretching north-south throughout the entire country, and the arid coast with the Sechura desert in the west (USAID, 2014a). The Amazon Basin (Selva), extending from the east, represents the majority of the country's forest area that covers nearly $60 \%$ of Peru's territory (FAO, 2016). Peru ranks ninth for its forest area in the world, significantly higher than the South American and OECD average (OECD/ECLAC, 2017).

Peru has one of the most productive seas in the world, which constitutes an important source of livelihoods for subsistence fish farmers. At the same time, forests are essential for meeting daily food, energy, shelter and human health needs, and particularly so for the nearly 333000 indigenous people living in the Peruvian Amazon (MINAM and MINAG, 2011). Of the total population, nearly $30 \%$ in Peru relies on forest resources for cooking and $10 \%$ for shelter (FAO, 2014). Forests also provide a variety of other important ecosystem services, such as habitat provisioning, erosion control, water regulation, carbon sequestration, and recreation and cultural values (Thompson et al., 2011).

\footnotetext{
${ }^{3}$ Based on a legal definition (i.e. informal worker is one who does not have the right to a pension when retired), $49.9 \%$ of workers in Peru were in informal employment in 2011. Based on a productive definition (i.e. an employee in a firm with five or fewer employees, a nonprofessional self-employed, or a zero-income worker), 59.4\% of workers were employed informally in 2012 (OECD, 2015).
} 


\subsection{Pressures on biodiversity and implications for long-term sustainability}

While Peru has abundant natural capital, economic development and growth have exerted pressure on biodiversity. A significant share of flora and fauna species are under threat ${ }^{4}$, as Peru has experienced a substantial deforestation rate over the past years, albeit below the regional average in South America ${ }^{5}$. The majority of deforestation activities are taking place in the biodiverse Amazonian regions (e.g. San Martin, Loreto and Ucayali) (Figure 1.1).

Figure 1.1. Cumulative deforestation in Peru by region, 2001-2015

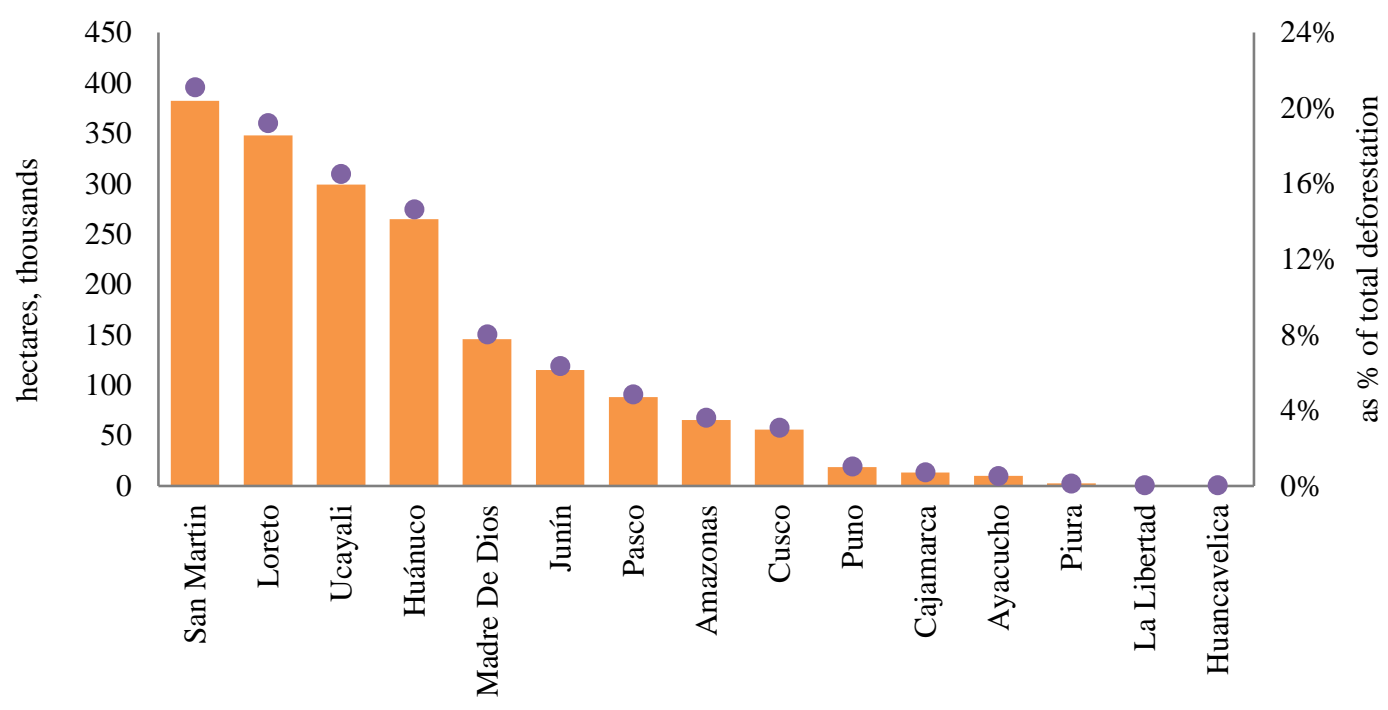

Source: Authors, based on the data retrieved from the website of MINAM's Geobosques Platform (accessed 23 January 2017)

The main pressures on biodiversity and forest loss in Peru are linked to land-use changes (USAID, 2014a). The expansion of the agricultural frontier alone accounts for up to $90 \%$ of deforestation (OECD/ECLAC, 2017). Large infrastructure projects, such as roads, also yield both a direct and indirect threat to biodiversity. The former refers to forest clearing, while the latter implies various catalysing effects, including illegal and informal activities through better connectivity and market access (USAID, 2014a).

The size of Peru's informal sector, closely linked to poverty and inequality, also poses a significant threat to biodiversity (Machado, 2014). Artisanal subsistence farming and fishing activities, albeit small scale and scattered, cumulatively pose a significant risk of overexploitation of natural resources in the Andes and coast. Marine ecosystems are also exposed to heightened pressures. These include overfishing, pollution and harmful fishing practices (OECD/ECLAC, 2017). Furthermore, sectors attracting the majority of illicit unregulated activities, such as illegal coca cultivation, logging and gold mining are also a

\footnotetext{
${ }^{4}$ In Peru, $44 \%$ of plant species, $8 \%$ of animal species, $36 \%$ of endemic bird species and $30 \%$ of endemic mammal species are under threat (USAID, 2014).

${ }^{5}$ Peru's total forest loss between 1990 and 2015 amounted to around 3.9 million ha or $0.2 \%$ per year. This represents a small part of 842 million ha of forest lost in South America in the same period, with an annual average of $0.4 \%$ (FAO, 2016).
} 
cause of biodiversity loss. According to estimates, illegal mining alone accounts for $30 \%$ of gold extraction in Peru (COMEX, 2014).

Deforestation can cost millions to the Peruvian economy in foregone ecosystem services. Guarín and Hotz (2015) estimate that land-use change in Cumbaza River watershed in San Martin region between 2013 and 2023 will undermine forest's carbon sequestration capacity, resulting in an economic loss of between USD 13.5 million and USD 368 million, depending on the carbon price applied. Similarly, for Sierra del Divisor National Park in Ucayali region, land-use change can cost between USD 40 million and USD 1.82 billion in non-sequestrated carbon. ${ }^{6}$

If these pressures persist, they are likely to undermine the future long-term sustainability of Peru's development and economic growth (MINAM, 2014a). Recognising these risks, the government has introduced various measures to conserve forests. Peru has announced a national commitment to achieve zero deforestation and conserve 54 million hectares of forest by 2021 (MINAM, 2011a). The government has also made a commitment in the context of Bonn Challenge and Initiative 20x20 to restore 3.2 million hectares of forests in degraded areas by 2020, of which 2 million hectares are envisaged to be achieved through commercial plantations and the rest through conservation (FAO, 2017). Peru is also engaged in the UN REDD+ programme, with several pilot projects underway supported by domestic and international finance (Box 5). In 2016, Peru finalised the formulation of the National Strategy on Forests and Climate Change (ENBCC), which is a comprehensive framework to address the country's deforestation challenge (OECD/ECLAC, 2017). The ENBCC is effectively a national REDD+ strategy, although its scope potentially extends beyond REDD+ initiatives (MINAM, 2016a).

\footnotetext{
${ }^{6}$ It is important to bear in mind that while carbon sink is an important ecosystem service provided by forests, the same level of sequestration can be achieved through both natural and planted forests. The latter, however, may be associated with a negative impact on biodiversity (OECD, 2018 forthcoming).
} 


\section{Mainstreaming biodiversity at national level}

\subsection{Institutional framework}

Over the past decade, Peru's institutional framework relevant for biodiversity has undergone significant transformation (OECD/ECLAC, 2017). In 2008, the Ministry of Environment (MINAM) was established, based on what was previously the National Council for Environment (CONAM). The elevation of the Council to the Ministry status has provided stronger policy leverage to environmental issues and has resulted in an extensive transfer of responsibilities from sector ministries and agencies to MINAM. A number of subsidiary bodies were also created (e.g. the Environmental Assessment and Oversight Agency, OEFA, and National Service of Certification for Sustainable Investment, SENACE) to support MINAM in carrying out its new mandate to design and implement national environmental policy, and ensure its coherence with sector policies (OECD, 2015). Figure 2.1 illustrates the framework of key environmental institutions.

OEFA's main function is to ensure enforcement of environmental legislation, including in four sectors: medium and large-scale mining; hydrocarbon and electricity; commercial fisheries and large-scale aquaculture; and the brewery, papermaking, cement and tannery industries (OECD/ECLAC, 2017). The environmental enforcement budget increased almost six-fold, from USD16 million in 2012 to USD 71 million in 2015, which allows more rigorous auditing of firms (OECD/ECLAC, 2017).

SENACE is responsible for evaluating EIAs of large-scale projects. Previously, compliance with environmental regulations and standards was under the mandate of individual line ministries. For instance, the Directorate General of Mining Environmental Affairs in the Ministry of Energy and Mines (MINEM) was in the past responsible for environmental impact assessments in the mining sector. However, significant concerns were raised regarding the potential conflict of interests between the objective of economic development of the mining sector and environmental considerations (Castro et al., 2014).

An extensive transfer of responsibilities for environmental assessments was initiated, with MINEM being the first ministry required to hand over its environmental functions to SENACE and OEFA. As of December 2017, besides MINEM, SENACE assumed the functions from transport, agriculture and sanitation sector authorities. The transfer process in other sectors is on-going, and according to the original schedule should be finalised in 2021, as OEFA and SENACE continue building the relevant technical expertise and capacity of their staff. Until 2017 SENACE's budget was gradually growing, however, in 2018 it declined from PEN 33.5 million to PEN 29.6 (MINAM, 2017), which may affect agency's ability to carry out its current, and assume new, responsibilities in a timely manner. 
Figure 2.1. Environmental institutional framework in Peru

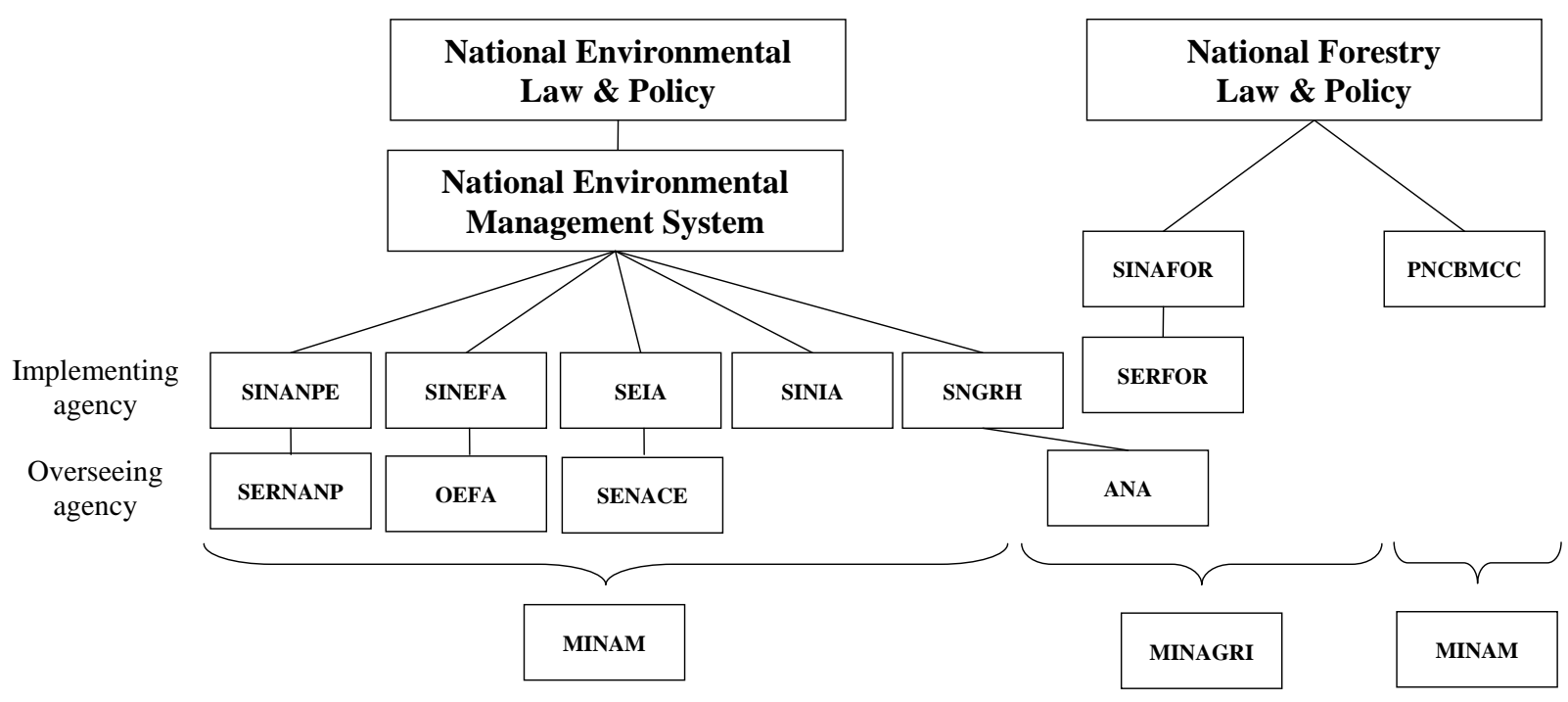

Source: Authors’ elaboration.

At the same time, certain policy areas remain within a shared domain with other ministries. For instance, forest policy is under joint-responsibility of MINAM and the Ministry of Agriculture and Irrigation (MINAGRI). Protected areas and forest conservation-related competences lie with the MINAM's National Service of Natural Protected Areas (SERNANP) and National Forest Conservation Programme for the Mitigation of Climate Change (PNCBMCC). The development of forest policy as a productive sector is under the responsibility of MINAGRI's National Forest Service (SERFOR ${ }^{7}$ ). Similarly, water and hydro-biological resources are jointly managed by several institutions, including MINAM, the National Water Authority (ANA) - a decentralised sub-entity of MINAGRI, and the Vice-Ministry of Fisheries in the Ministry of Production (PRODUCE) (OECD/ECLAC, 2017; USAID, 2014a). Overall, this arrangement seems to work well, as the co-ordination between MINAM and MINAGRI has improved and governance of forest and water resources has strengthened (OECD/ECLAC, 2017). Nevertheless, there needs to be a clear distinction between roles and responsibilities in the overlapping policy domains to avoid potential duplication and conflict of interests (USAID, 2014a).

\section{Cross-sector co-ordination is essential for the success of mainstreaming}

To further help clarify the roles of individual institutions in coherent management of biodiversity conservation and its sustainable use, and monitor their respective progress, strong inter-ministerial cross-sector co-ordination is required. In an effort to achieve such co-ordination, the National Commission on Biodiversity (CONADIB) was created as a public-private forum, in charge of monitoring the implementation of the NBSAP (MINAM, 2009). CONADIB meets regularly, including through a number of technical groups focusing on various themes, such as agro-biodiversity, protected areas or urban biodiversity.

\footnotetext{
${ }^{7}$ Traditionally, forest policy and conservation policy were both MINAGRI competences - i.e., since the 1963 Forestry Law (Dourojeanni, 2009).
} 
CONADIB has broad membership ${ }^{8}$ including, amongst other stakeholders, indigenous communities, represented by the Inter-ethnic Association for Development of the Peruvian Amazon (AIDESEP) and the Confederation of Amazonian Nationalities of Peru (CONAP). However, there is a need to secure higher level political representation and influence, and to strengthen commission's technical capacity, so as to increase its effectiveness in practice. Furthermore, while one of the key functions of CONADIB is to promote dialogue between private and public sector on the matters concerning biodiversity conservation and management, the participation from the private sector remains modest, limited to trade unions and associations.

At the same time, to ensure that environment and biodiversity are adequately incorporated across the economy, a Multi-Sector Commission was created in 2012. Its main task is to develop proposals to improve environmental and social conditions in all economic activities, with a particular focus on the extractive sector (Castro et al., 2014). The Commission brings together a number of key ministries ${ }^{9}$, and is chaired by the Presidency of the Council of Ministers, with MINAM serving as the Secretariat. In the same year, the Commission proposed the Strategic Axes of Environmental Management which were approved by the Council of Ministers (Castro et al., 2014).

While significant steps have been made to achieve institutional co-ordination, the relationships and links between different bodies and their mandates within the emerging environmental institutional framework could be further strengthened and formalised. This is particularly important for achieving the national biodiversity targets under the NBSAP, discussed below.

\section{Decentralisation creates significant challenges}

Over the past three decades, Peru's institutional framework experienced a number of transitions, from a centralised regime to decentralisation in 1979, and to re-centralisation in the 1990s. Finally, as the country returned to democracy, a new phase of decentralisation started in 2002, and is presently still ongoing. Peru developed a composite regional government system comprising 25 departments. It is also the only Latin American economy that has a two-level local government system with 196 provinces and 1853 districts (OECD, 2015). The decentralisation agenda aims to increase fiscal resources and political powers of these sub-national governments, including in the environmental domain, in order to reduce stark inter-regional disparities (OECD, 2016b).

However, as sub-national governments received more responsibilities for policy implementation, their administrative and technical capacity continue to lag behind (Box 1). They also tend to experience a lack of financial resources (OECD, 2015). Sub-national government system is also often characterised by political fragility, lack of clarity on roles and responsibilities of different tiers of the government, and limited co-ordination with the central government (OECD, 2015). In view of this, the OECD Public Governance Review of Peru (2016b) identifies a need for a more deliberate effort to increase financial autonomy of sub-national governments, and provide greater institutional and administrative support to implement their mandates (OECD, 2016b).

8 There are twenty member institutions and twelve technical groups led, amongst others, by MINAM, IMPARPE, SERNANP, MINAGRI and PRODUCE.

${ }^{9}$ MINAM, MINAGRI, PRODUCE, MINEM, Ministry of Finance (MEF), Ministry of Health (MINSA), Ministry of Development and Social Inclusion (MIDIS), and Ministry of Culture. 
Recognising these challenges, Peru has made significant efforts to improve the career prospects and capacity of the civil servants, launching a large-scale civil service reform seeking to professionalise the public sector, targeting all tiers of the government (Box 1). In this context, the achievement of the NBSAP strategic objective on strengthening the capacity to sustainably manage biodiversity at all levels of government gains particular importance (Box 4). The NBSAP overall promotes decentralisation, by assigning subnational governments significant responsibilities for its implementation.

\section{Box 1. Public sector capacity challenges and turnover}

One of the main challenges for institutional effectiveness in Peru is a lack of stable and professional civil service system (OECD, 2016b). The civil service in Peru is characterised by high personnel turnover particularly at the sub-national level, driven in part by the prevalence short-term staff contracts (USAID, 2014a). More than 70\% of first and second-level managers are 'positions of trust', which results in every change in political power being associated with extensive staff turnover, going beyond the top level leadership (OECD, 2016b). This significantly undermines the capacity of the environmental institutional framework, and the continuity in environmental policy, both at national and sub-national level.

There are also limited incentives for talent to join the civil service, given the lack of transparent and meritocratic selection process, and guarantees of employment stability and career progression. Moreover, given the acute spatial economic disparities between Lima and the rest of the country, remote regions can hardly offer the same academic and professional opportunities as those that exist in the capital (OECD, 2016c). This results in significant human resource deficiencies, particularly in sub-national authorities.

To address these challenges, a large-scale reform, designed and implemented by the National Civil Service Authority (SERVIR), is underway with a formidable agenda to restructure a system of 600000 civil servants across three tiers of the government. The main instrument of the reform, the new Civil Service Law (30057), has been developed according to the best practice across OECD countries, aiming to professionalise the civil service, using the principles of merit and equal opportunities to limit the share of political appointees and attract highly qualified professionals into government jobs.

\subsection{Legal framework}

Peru also achieved significant progress in developing a legal framework to support the implementation of environmental policies. Some of the key milestones in legislation for biodiversity include:

- The Law on Conservation and Sustainable Use of Biodiversity (Law 26839, 1997) created a legal basis for the implementation of the objectives of the UN Convention on Biological Diversity, including the formulation of the NBSAP.

- The Organic Law for Sustainable Use of Natural Resources (Law 26821, 1997) defines the terms and conditions for granting private concessions, aiming to strike a balance between economic growth, and conservation and sustainable use of natural resources. The Law, together with the Regulation on Classification of Lands by their Best use Capacity passed in 2009 also laid the ground to the development a best-use capacity classification system to determine an appropriate land-use type, 
e.g. agriculture, livestock, forestry or conservation (clasificacion de capacidad de uso mayor de la tierra).

- The Natural Protected Areas Law (Law 26834, 1997) determines management and conservation of biodiversity in both marine and terrestrial protected areas.

- The Law on the National Environmental Impact Assessment System (SEIA) (Law 27446, 2001) creates a framework subjecting all private and public projects to Environmental Impact Assessments (EIA). Supporting regulations passed in 2009 require all EIAs to incorporate a valuation of ecosystem services (Article 25) and a detailed assessment of environmental impact of a planned activity, including the cost of mitigation, monitoring, and compensation for any damage caused (Article 26) (Box 2).

- The General Environment Law (Law 28611, 2005), besides lending overarching support to the environment policy agenda, also determines a decentralised approach to the land-planning process, seeking to promote sustainable management of natural resources. MINAM has the role of overseeing and co-ordinating the process, including the current work on Ecological Economic Zoning, which will serve as a basis for the development of a comprehensive land-use plan (USAID, 2015a).

- The Forestry and Wildlife Law (Law 29763, 2011), that replaced 2000 Law, is a landmark for sustainable forest management, making provisions for concessions for forest and agro-forest plantations on public lands in the Amazon. Accompanied with regulations, the Law also determines key principles for inclusive access to, and a sustainable use of, forest resources by all people. Importantly, Article 3 makes it mandatory to conduct consultations with indigenous peoples prior to developing new legislation that may affect their territories and rights (MINAG 2012; 2013) (Box 3). The Law has created the National Forest and Wildlife Service (SERFOR), and been instrumental for the formulation of the Forest and Wildlife National Policy in 2013.

- Law on Compensation Mechanisms for Ecosystem Services (Law 30215, 2014) aims to promote and oversee Payment for Ecosystem Services (PES) schemes that channel public and private financial flows for conservation, restoration and sustainable use of ecosystem services. Regulations approved in 2016 provide additional clarity on the implementation of PES initiatives, and serve as a legal signal to mobilise investment for ecosystem services (Jenkins et al., 2016). SERNANP also issued a resolution in 2014 (26-2014-SERNANP) which allows PES schemes, including REDD+ projects, to operate within the national protected areas subject to management agreements with protected areas (Wieland Fernandini and Sousa, 2015). 


\section{Box 2. History and reform of Environmental Impact Assessment in Peru}

The evolution of Environmental Impact Assessment (EIA) in Peru has a long history. The EIA concept was first introduced in 1990 by the National Code for Environment and Natural Resources (Legislative Decree 163). EIA became the main tool for implementing environmental policy objectives. At this time, the responsibility to review and approve EIAs lied with each sector ministry. In 1997, CONAM was given the function to formally oversee this process (Castro et al., 2014). However, EIA faced a strong opposition from the sectors which viewed it as an obstacle to their economic development (Castro et al., 2014). EIA's structure was also fragmented and poorly coordinated, with insufficient clarity on its main purpose as a tool for environmental planning or environmental management. This ambiguity and lack of credibility rendered EIAs less effective in achieving environmental priorities in the context of an economic growth agenda (World Bank, 2007).

In response, the government initiated an extensive EIA reform. Passing the law on SEIA, and creating MINAM and SENACE, contributed to strengthening the system. Established as a one-stop shop for environmental certification, SENACE is responsible for granting environmental permits as well as for directly evaluating large-scale projects with a potentially significant impact on environment, i.e. conducting a detailed EIA. There are two other types of EIAs for smaller projects - Environmental Impact Statement (DIA) and Semi-Detailed Environmental Impact Study (EIAsd). There are specific legally-determined time limits for completing each type of EIA and an aim to fast-track environmental certification to promote investment and economic development. While concentrating environmental certification within SENACE should aid inter-sector coordination and streamline the process, it is important that the attempt to accelerate the process does not come at the cost of environment and biodiversity (OECD/ECLAC, 2017).

\section{Effectiveness of the legislative framework depends on the rigour of its implementation and bridging the existing gaps}

The strength of the environmental legislative framework is contingent on its effective enforcement in practice. Peru's legislative system faces a number of challenges in this regard, including a need to improve enforceability of laws and efficiency and transparency of legal procedures. The ability of the legislative branch to fight corruption and illegal activities also needs to be enhanced. An improvement in implementing checks and balances imposed on the executive by the legislature is also important (OECD, 2015). Moreover, the legal framework governing decentralisation process remains fragmented, and is fraught with complexity and difficulties in implementation (OECD, 2016b). Addressing these challenges would help build trust of the public in the strength of the governance system and state legitimacy, and improve the efforts to tackle illegal and informal activities that are often associated with a significant damage to biodiversity and ecosystem services.

At a more technical level, several loopholes exist in the legal system in relation to the sustainable management of natural capital. First, concessions tend to be granted individually for each sector, e.g. mining, oil, gas or forest. This may result in cases where multiple overlapping concessions are allocated for a certain area, leading to conflicts between the parties holding the rights. Second, there has been criticism on the principle of 
granting a land title based on an 'improvement' applied to a land parcel. Given that cutting down trees may in some cases be viewed as such an improvement, this approach may serve as a disincentive for forest conservation or sustainable use, thus driving deforestation (USAID, 2014a). Third, it is argued that the land capability classification principle of designating a land use based on land productivity is focused on maximising utility, while it does not sufficiently take into account environmental and social impact of an activity (USAID, 2015a). Moreover, productive capacity of landscape from an ecosystem services perspective is not always evident, and requires specialised assessment.

\section{Engaging indigenous peoples and local communities}

Successfully engaging indigenous peoples and local communities in consultations regarding government decisions that may have an impact on their communities and the land they reside in is also an important criterion of an adequately functioning legal framework. There are multiple examples of social conflicts sparked by the infringement of indigenous peoples' rights in implementing legal and administrative measures. For instance, in an effort to adapt the country's legal framework to the requirements of the 2006 Peru Trade Promotion Agreement with the United States (PTPA), the government issued a number of legislative decrees in 2008 (Greenspan, 2011). These decrees invoked an active protest by indigenous peoples groups and civil society. It was argued that, among other implications, some of the decrees would subject 45 million hectares of forest to the risk of conversion for various uses, including agriculture. The conflict spiralled into a violent clash leading to casualties, but was eventually resolved by the revocation of the controversial decrees, and the introduction of prior consultation legislation (Box 3) (EIA, 2012). 


\section{Box 3. Indigenous peoples in the management of the Peruvian Amazon}

In 2008, the Administration of the President Garcia issued 99 Legislative Decrees, commonly referred to as the "Law of the Jungle", some of which would affect the use of ancestral lands and managing the Peruvian Amazon, sparked a prolonged indigenous strike. The decrees were signed under the special powers delegated to the government by the Congress to implement the PTPA with the United States, and did not involve prior consultations with the indigenous communities. According to legal experts and indigenous organisations, including AIDESEP, at least nine of the decrees were in breach of the government's obligation under the Indigenous and Tribal Peoples Convention (ILO Convention 169) to consult indigenous communities. Moreover, under the Peruvian Constitution, indigenous communities have the right to consultations and participation in decision making processes affecting their territories (EIA, 2012; Rénique, 2009).

Some of the decrees were of particular controversy. For instance, DL 1090, the Forestry and Wildlife Law, amended the definition of forest patrimony, reducing the forest area under the Forestry Heritage protection system, effectively releasing 45 million hectares or $60 \%$ of Peruvian forests for potential forest concessions. DL 1015 and 1073 were criticised for promoting private investment in the indigenous lands, facilitating the fragmentation in the ownership of communally-owned territories. The two decrees permitted indigenous communities to decide on the sale of their land with a simple majority vote, instead of the previous the two-third requirement. Finally, DL 1064 eliminated the prerequisite for the extractives companies to seek an agreement from land owners, prior to initiating operations on their territory (FIDH, 2009).

While the government made some efforts to amend the decrees, these were deemed insufficient, with the unrest gradually escalating, leading to road and river blockages by indigenous groups across the Amazon and the declaration of the state of emergency. The conflict reached its peak on 5 June 2009 in the province of Bagua where a violent confrontation between police and protesters killed 33 people. In response to the bloodshed, the Law of the Jungle was repealed, and the legislation to introduce mechanisms for prior consultation with indigenous peoples was adopted (EIA, 2012; Rénique, 2009).

An important milestone for engaging indigenous peoples in sustainable forest management in Peru was the adoption of the Forestry and Wildlife Law in 2011. The Law was preceded by a consultation process - the Forestry Law Platform which brought together the representatives of civil society, indigenous organisations, academia, government and professional organisations. However, as it was the first such experience of prior consultation for both the government and stakeholders, several deficiencies in the process remained. For instance, there was no clarity on the criteria used by the government to decide which stakeholder inputs to include in the Law (EIA, 2012).

The new Forestry and Wildlife Law determines key principles for inclusive access to, and a sustainable use of, forest resources by all people. It also adopts an ecosystem-based approach to forest and wildlife management. Importantly, Article 3 makes it mandatory to conduct consultations with indigenous peoples prior to developing new legislation that may affect their territories and rights. In 2015, bylaws referred to as 'Productive Forests for Life' were adopted to guide the enforcement of the Forestry and Wildlife 
Law. The regulations pay a significant attention to forest management by the indigenous peoples, and promote forestry businesses by local and indigenous communities (WWF, 2014).

In addition, the Peruvian Congress unanimously approved in 2011 the Law on the Right of Consultation of Indigenous Peoples Law (29785), in recognition of the Convention 169 of the International Labor Organization (ILO) on Indigenous and Tribal Peoples. Peru has been signatory to the Convention since 1993, but had not implemented it at the national statutory level (Rodriguez-Ferrand, 2011). The Consultation Law requires the government to consult indigenous peoples to secure their agreement before implementing administrative and legal measures, or development projects that may affect their ancestral territories.

Provided effective enforcement, the Consultation Law could be a useful instrument to reduce social conflicts (Greenspan, 2011). The successful implementation is contingent on addressing a number of gaps, as identified in the report by the UN Special Rapporteur on the Rights of Indigenous Peoples (UNHRC, 2014). These include, amongst others, improving government capacity, ensuring that consultations take place before the issuance of mining concessions, and involving indigenous peoples throughout the life cycle of projects (Greenspan, 2014).

\subsection{Data availability and quality}

\section{Peru has a history of data collection and scientific research for natural resource management}

The attempts to create an integrated and evidence-based policy planning process for natural resource management in Peru date back to the 1960s, when the National Office for Natural Resources Evaluation (ONERN) and the Marine Institute of Peru (IMPARPE) were created. ONERN was instrumental to systematic data collection on natural resources, informing the formulation of national economic and social development plans (Castro et al., 2014). However, ONERN was closed as a result of the 1990s reforms. IMPARPE as a technical agency of the Ministry of Production (PRODUCE) has an important role in scientific research informing policy-making in the domains of conservation and sustainable use of marine resources. Information generated by IMARPE is publicly available in its digital repository. Further, the government's efforts to promote sustainable forest management are supported by the Peruvian Amazon Research Institute (IIAP), established in 1981. Operating under MINAM's authority, IIAP is responsible for scientific and technological research, with a focus on integrated forest management and environmental services extending to the whole Amazon basin covering $760000 \mathrm{~km}^{2}$ (IIAP, 2018).

Over the past years, investment into scientific research on natural resource-related issues has seen a steady increase, reaching PEN 61.28 million in 2013 (MINAM, 2014b), a substantial level compared to the overall public expenditure on biodiversity (Section 2.5). Examples of recent efforts in key areas of biodiversity research include the creation of the National Institute for Research on Glaciers and Mountain Ecosystems (INAIGEM) was created. Established in 2014 under MINAM's authority, INAIGEM aims to promote scientific research in the area of mountain ecosystems, in particular glacial sub-basins to improve their sustainable management in the face of climate change-related risks (INAIGEM, 2018). 
An important milestone is also the formulation of the National Cross-cutting Programme of Science, Technology and Technological Innovation for the Valuation of Biodiversity (Valbio) 2015-2021. The Valbio's development was led by the National Council for Science, Technology and Technological Innovation (CONCYTEC) and an interinstitutional committee, involving academia, government and international co-operation (OECD/ECLAC, 2017). According to CONCYTEC's assessment in the lead up to the formulation of the Valbio programme, Peru ranked at the bottom amongst other South American countries, based on the number of scientific studies conducted in the area of science and technology. However, the share of studies concerning biodiversity-related issues was considerable, amounting to an average of nearly 30\% between 2011 and 2014 (CONCYTEC, 2015). As a result, to further improve scientific research in this area, the programme aims to engage a wide array of economic actors, including the private sector, in order put value on biodiversity. To this end, the Valbio seeks to strengthen capacity for research and generating the required new relevant scientific and technological knowledge, and applying novel technologies and production processes (CONCYTEC, 2015). In addition, CONCYTEC has formulated national programmes on biotechnology and environmental science and technology.

\section{Attempts are being made to harmonise scattered sector data, improve its quality and coverage}

Despite the evolving capacity to collect and analyse environment-related data, it is often fragmented and scattered between different authorities and levels of government. Even when the data is gathered, it is not always made publicly available or shared with other government entities. The current quality of biodiversity-related data is considered insufficient by CEPLAN to permit a comprehensive national evaluation of biodiversity and to formulate concrete measures to promote conservation and sustainable use (CEPLAN, 2011).

Recognising the importance of data and information in understanding the implications of economic development for biodiversity, the government has made efforts to fill the gaps in the knowledge base. The National System of Environmental Information (SINIA) is a major achievement in this regard. It collects and compiles information and data from a number of authorities on ten thematic areas ${ }^{10}$, which includes a number of biodiversityrelevant information platforms (Table 2.1). The websites of SINIA and its information platforms provide downloadable data for further analysis and research to inform policy making and academic debate in the area of biodiversity mainstreaming.

10 These are water; air and climate; climate change; environmental management; natural resources; waste, environmental health, land and territory; social aspects; and economic activities. 
Table 2.1. Biodiversity-relevant information platforms within National System of Environmental Information (SINIA)

\begin{tabular}{ll}
\hline \multicolumn{2}{c}{ Information platforms } \\
\hline National mapping service & GEOSERVIDOR \\
Platform to monitor changes in forest cover & GEOBOSQUES \\
Air quality information system & INFO AIRE PERU \\
National platform of ecosystem services & PNSE \\
Registry of pollutant emissions and transfer & RETC \\
Amazon biodiversity information system & SIAMAZONIA \\
Solid waste management information system & SIGERSOL \\
OEFA's national environmental complaints system & SINADA \\
Water resource information system & SNIRH \\
Historical data of agricultural production & AGRICOLA \\
Geological mining cadastre information system & GEOCATMIN \\
Online enquiry system on aquaculture rights & ACUICOLA \\
Online enquiry system for fishing vessels & EMBARCACIONES \\
\hline
\end{tabular}

Source: Authors, based on the information retrieved from the website of the National System of Environmental Information (SINIA)

Of the information platforms directly relevant for biodiversity, GEOSERVIDOR is one of the most advanced. It includes information on deforestation, land use, legal and illegal mining, as well as risks and vulnerabilities. An important product of GEOSERVIDOR is the information system on the change in forest cover - GEOBOSQUES. It includes an early alert system developed by the laboratory of Global Land Analysis and Discovery at the University of Maryland, using Landsat satellite images. SERFOR also seeks to develop an overarching Satellite Forest Resources Account to map timber and non-timber forest resources, wild fauna and ecosystem services.

To further improve the information on the country's forest resources, the first national forest inventory was initiated in 2012. The inventory is jointly conducted by MINAM and MINAGRI, and supported through technical co-operation from FAO and Finland. Besides collecting information on the state of forests, the inventory also aims to improve the understanding of the existing barriers to sustainable forest management and the links to communities (MINAGRI, 2016).

Another potentially important ecosystem-related information system is PNSE, which is a pre-registration tool for compensation mechanisms for ecosystem services (MRSE). While PNSE is in its initial stage of development, the tool is expected to gain momentum given that the regulations for the MRSE Law were passed in July 2016. The PNSE tool will allow systematising and mapping compensation initiatives country-wide. 
GEOSERVIDOR and PNSE have also the potential to inform and feed into the MINAM's national land-use planning policy. The exercise has started with a technical study on economic and ecological zoning (ZEE). The ZEE study includes an integral diagnosis of the territory, aiming to classify landscapes by the type of climate, soil, biodiversity, and ecosystem services, at three levels: micro (community or forestry concession), meso (district or province) and macro (regional). ZEE will form the basis for the development of a comprehensive national land-use plan. Such an approach to land-use planning is relatively new and seeks to conserve biodiversity and the environment, while ensuring the country's socio-economic development. ZEE has been 60\% completed at macro-meso levels (USAID, 2015a). There are currently 13 ZEE approved at regional level, and six at the provincial district level (GEOSERVIDOR, 2014).

The San Martin region has piloted a project to develop ecosystem accounts for the region which have demonstrated the significance of ecosystem services for the economy. The project was conducted by Conservation International's Ecosystem Values, Assessment and Accounting (EVA) and served as a case study for the World Bank's Wealth Accounting and the Valuation of Ecosystem Services (WAVES) initiative. The results show that although ecosystems had declined by 3.6\% between 2009 and 2013, they contributed USD 58 million to the regional economy, effectively making them the eighth largest sector (Conservation International, 2016).

\subsection{National plans and strategies}

National Biodiversity Strategies and Action Plans (NBSAPs) are key strategic documents under the United Nations Convention on Biological Diversity (CBD), guiding the process of managing countries' biodiversity and therefore have an important role to play in also driving biodiversity mainstreaming. For the effective implementation of an NBSAP, it should have specific strategic objectives and priority actions, and define time-bound and measurable targets and indicators to monitor progress towards achieving the specified objectives and actions (OECD, 2018 forthcoming).

Peru's National Biodiversity Strategy (NBS) 2014-2021 and National Biodiversity Action Plan 2014-2018, jointly referred hereafter as 'NBSAP', acknowledge the need for reciprocal mainstreaming of biodiversity and development objectives (MINAM, 2014a). The NBSAP recognises the need to strengthen the principle of ecosystems-based development planning, understood as the integrated management of land, water, and living resources. Emphasis is also placed on coherent inter-sectorial policy making, which is explicitly reflected also in Peru's national development agenda - the Peru 2021 Bicentennial Plan, discussed further below.

The NBSAP also introduces an overarching concept of 'productive conservation' which aims to integrate biodiversity conservation, ecosystem services and sustainable use of natural resources to achieve benefits for indigenous peoples and local communities in rural areas.

\section{Peru's NBSAP features a detailed matrix to support implementation}

Peru's NBSAP has a clear structure and an implementation matrix, which defines 13 National Biodiversity Targets (NBT) under six strategic directions, and respective indicators, baselines, and a detailed list of 147 actions to be undertaken. The NBSAP also identifies the alignment of each NBT with individual Aichi Biodiversity Targets. 
With respect to mainstreaming biodiversity, the NBSAP formulates a number of relevant objectives, targets and indicators (Box 4). For instance, one of the six strategic objectives is the increased contribution of biodiversity to national development, by improving the country's competitiveness and equitable sharing of benefits. The strategic objective details targets, priority actions and indicators, with an aim to promote bio-businesses and marketing of their bio-products nationally and internationally. At the same time, the NBSAP also seeks to address, amongst others, the impacts of mining activities, and particularly those of illegal mining.

Besides horizontal inter-sectoral mainstreaming, the NBSAP also pays significant attention to vertical mainstreaming across different levels of government (IDLO, 2016). It focuses on developing sub-national biodiversity strategies and strengthening capacity of all tiers of the government (Strategic Objective 6; Target 9).

The importance of reducing inequality is also recognised, with poverty reduction and social inclusion being implicitly integrated throughout the document as part of the inclusive development vision. More specifically, poverty reduction and social inclusion are addressed in the context of equity in ensuring the access to biodiversity and its benefits (Targets $4,5,13$ ), and in relation to the productive conservation approach (MINAM, 2014a).

The process of monitoring and evaluation of the progress towards achieving the NBTs is effectuated through software, which reports to the CONADIB and collects data from the institutions leading on NBSAP actions. MINAM is leading on gathering baselines for all the indicators as defined in the NBSAP. 


\section{Box 4. Focus on biodiversity mainstreaming in Peru's NBSAP}

Improving sustainable use of biodiversity and reciprocal integrating biodiversity in development planning is a central theme of Peru's NBSAP, which is exemplified in a number of strategic objectives, and related targets, indicators and priority actions. Some relevant examples from the implementation matrix include:

Strategic Objective 2: Increase the contribution of biodiversity to national development by improving the country's competitiveness and equitable distribution of benefits.

Target 4: Recognise five ecosystem services, ensuring the integrity of ecosystems and respect for indigenous peoples involved, and a similar number of competitive biobusinesses have been promoted, preferably oriented on the model of bio-trade, achieving marketisation of two new value added products (associated Aichi Biodiversity Targets 2 and 14).

Indicator 4.1: Number of offset mechanisms for ecosystem services implemented.

Baseline: Zero ecosystem services offset mechanisms.

Indicator 4.2: Number of competitive bio-businesses that sell biodiversity-based products the national and international markets.

Baseline: 89 competitive bio-businesses oriented on the BioTrade model.

Actions include technical and legal instruments for economic and non-economic valuation of biodiversity and ecosystem services; a monitoring system for ecosystem service valuation, including REDD+ projects; and the approval of mechanisms for incorporating the valuation of biodiversity and ecosystem services in national accounts.

Strategic Objective 3: Reduce direct and indirect pressures on biodiversity and ecosystem processes

Target 7: Reduce the rate of ecosystem degradation by 5\%, with emphasis on forest and fragile ecosystems (associated Aichi Biodiversity Targets 5 and 15).

Indicator 7: Rate of national deforestation.

Baseline: Rate of national deforestation of $0.136 \%$ over $2000-2005$.

Actions include developing a guide of good corporate practices of biodiversity conservation for mining and hydrocarbons companies; and implementing measures to control activities that cause biodiversity degradation, amongst others illegal mining.

Strategic Objective 4: Strengthen the capacities of the three levels of government for the sustainable management of biodiversity

Target 9: Further strengthen institutional capacities at all levels of government, to ensure effective and efficient management of biodiversity (associated Aichi Biodiversity Target 1).

Indicator 9.1: Number of regional governments that have Strategies and Plans of Action for the management of biodiversity in implementation 
Indicator 9.2: Percentage of provincial and district municipalities that carry out activities within the framework of the respective Regional Biodiversity Strategy and Action Plan

Baseline: Ten regional biodiversity strategies and action plans have been approved and are being implemented.

Actions include the development of regional biodiversity strategies, and incorporation of conservation and sustainable/productive use of biodiversity in concerted regional development plans.

Source: MINAM (2014a), National Biodiversity Strategy 2021 and National Action Plan 2014-2018.

\section{Respective roles of institutions responsible for implementation could be better defined}

The NBSAP determines institutions responsible for the implementation of each of the 13 NBTs (Table 2.2). Given the multiplicity of actions envisaged under each target, it is important that the implementation process has a clear definition of institutions' respective roles in completing specific actions and their prioritisation of different actions ${ }^{11}$. For instance, under Target 1 on effective and sustainable management of biodiversity, there are 20 actions to be achieved between 2014 and 2018, with six responsible parties for their delivery. Since the distinction between lead and assisting institutions is not identified, there is limited clarity on which institution and to what extent should be held responsible in case of achievement or underachievement of an action and the target.

\section{The NBSAP was developed through extensive stakeholder consultations}

Peru's NBSAP stands out for being developed through an extensive participatory process, according to the recent assessment of countries' post-2010 NBSAPs (IDLO, 2016). The consultation process in Peru was led by MINAM in collaboration with the multi-sector National Commission of Biodiversity (CONADIB) that brings together 20 public institutions and private sector organisations. As part of the process, a number of workshops were convened covering a total of 800 participants. The consultations were also open to the public online, and every contributor was notified whether their inputs were taken into account or rejected and for what reasons.

Developing the NBSAP in a consultative manner is key to ensuring that the interests of different stakeholders, including indigenous communities, are adequately reflected. There are several precedents of social conflicts in Peru caused by the infringement of indigenous peoples' rights in relation to socio-economic and environmental issues, discussed above (Section 2.2.; Box 3).

${ }^{11}$ During the consultations, MINAM stated that responsible parties have been identified for the implementation of specific actions. 
Table 2.2. Institutions responsible for implementation of National Biodiversity Targets

\begin{tabular}{|c|c|c|c|c|c|c|c|c|c|c|c|c|c|}
\hline \multirow[t]{2}{*}{ State institution } & \multicolumn{13}{|c|}{ National Biodiversity Targets } \\
\hline & 1 & 2 & 3 & 4 & 5 & 6 & 7 & 8 & 9 & 10 & 11 & 12 & 13 \\
\hline \multicolumn{14}{|l|}{ Ministry of Environment } \\
\hline \multicolumn{14}{|l|}{ Ministry of Agriculture } \\
\hline \multicolumn{14}{|l|}{ PRODUCE } \\
\hline \multicolumn{14}{|l|}{ Ministry of Tourism } \\
\hline \multicolumn{14}{|l|}{ MINCU } \\
\hline \multicolumn{14}{|l|}{ MINEDU } \\
\hline \multicolumn{14}{|l|}{ MRE } \\
\hline \multicolumn{14}{|l|}{ PCM } \\
\hline \multicolumn{14}{|l|}{ SERNANP } \\
\hline \multicolumn{14}{|l|}{ SERFOR } \\
\hline \multicolumn{14}{|l|}{ OEFA } \\
\hline \multicolumn{14}{|l|}{ OSINFOR } \\
\hline \multicolumn{14}{|l|}{ SENACE } \\
\hline \multicolumn{14}{|l|}{ IMARPE } \\
\hline \multicolumn{14}{|l|}{ INIA } \\
\hline \multicolumn{14}{|l|}{ IIAP } \\
\hline \multicolumn{14}{|l|}{ SENASA } \\
\hline \multicolumn{14}{|l|}{ SANIPES } \\
\hline \multicolumn{14}{|l|}{ ITP } \\
\hline \multicolumn{14}{|l|}{ CONCYTEC } \\
\hline \multicolumn{14}{|l|}{ SUNAT } \\
\hline \multicolumn{14}{|l|}{ INDECOPI } \\
\hline \multicolumn{14}{|l|}{ Ecological police } \\
\hline \multicolumn{14}{|l|}{ National police } \\
\hline DICAPI & & & & & & & & & & & & & \\
\hline MPFN & & & & & & & & & & & & & \\
\hline Judiciary & & & & & & & & & & & & & \\
\hline Regional governments & & & & & & & & & & & & & \\
\hline Local governments & & & & & & & & & & & & & \\
\hline Universities & & & & & & & & & & & & & \\
\hline Research institutes & & & & & & & & & & & & & \\
\hline
\end{tabular}

Source: Authors, based on the information provided in Peru’s NBSAP (MINAM, 2014a).

\section{The government seeks to strike a balance between production and conservation by integrating biodiversity within national development plans and strategies}

Along with integrating development dimension into biodiversity policy, efforts are being made to mainstream biodiversity across the national development agenda. To this end, a policy framework - Strategic Axes for Environmental Management - was developed by the Multi-Sector Commission to implement gradual and consistent incorporation of the environmental dimension, including biodiversity, into national and sector policies (MultiSector Commission, 2012). Biodiversity conservation and sustainable use is for the country's sustainable development, and proposes practical steps towards its implementation. These include the revision of the National Forestry and Wildlife Policy, adoption of legislation on offset mechanisms for ecosystem services, and strengthening 
forest management institutions (see Section 2.1 and 2.2) (Multi-sectoral Commission, 2012).

In line with the goals of the strategic axes for environmental management, biodiversity is incorporated in Peru's long-term national development plan, Peru 2021 Bicentennial Plan, through one of its six strategic axes - 'natural resources and the environment'. The Plan, formulated by the National Centre for Strategic Planning (CEPLAN), identifies biodiversity, along with water, soil, forests and hydro-biological resources, as a key natural resource for the country's development (CEPLAN, 2011). The Plan elaborates biodiversity-specific goals, priority actions, indicators and targets, and includes cost estimates to implement the underlying programmes.

The management of Peru's natural resources is further guided by the National Productive Diversification Plan (PNDP). The main aim of the PNDP is to achieve sustainable economic growth, through reduced dependence on natural resources, and increased productivity and formal employment (PRODUCE, 2014). The Plan recognises the importance of more effective use of natural resources, including biodiversity and forests, as a driver for the country's economic growth. The PNDP also makes a reference to the National Environmental Action Plan and one of its five strategic objectives is "to achieve eco-efficient and competitive development of the public and private sectors, promoting national and international economic and environmental potential and opportunities".

Furthermore, the PNDP identifies the development of the forest industry as key for the country's economic diversification (PRODUCE, 2014). To this end, it considers regulatory reforms and the provision of subsidies to the forestry sector (OECD, 2016a). While the creation of a formal appropriately regulated forestry sector is important to address illegal activities and alleviate pressures on biodiversity, it is equally important to ensure that this does not lead to overexploitation and depletion of forest resources.

Therefore, Peru seeks to strike a balance between production and conservation to develop a sustainable forestry sector through the National Forestry and Climate Change Strategy (ENBCC). The ENBCC pursues a 'production-conservation approach' which seeks to increase landscape productivity, while achieving forest conservation (Jenkins et al., 2016). Peru is also tenth in the world with the largest area designated to forest biodiversity conservation, amounting to $27 \%$ of total forest cover (FAO, 2016). For more discussion on mainstreaming biodiversity in the forestry sector, see Chapter 4 .

Another important sustainable development policy is forthcoming as part of the Partnership for Action on Green Economy (PAGE), a joint initiative between five UN agencies ${ }^{12}$. Peru was one of the first countries that PAGE supported in identifying the main opportunities and components required for a long-term growth model based on a green economy (PAGE, 2015). To inform this process, an exercise to model the costs and benefits of a transition to a green development path, with a focus on agriculture, forestry, and urban transport was completed and published in 2017 (PAGE, 2017). PAGE works in co-operation with MINAM, Ministry of Labour and Employment Promotion (MTPE), MEF, CEPLAN and the University of the Pacific.

12 The United Nations Environment Programme (UNEP), the International Labour Organization (ILO), the United Nations Program for Development (UNDP), the United Nations Industrial Development Organization (UNIDO) and the United Nations Institute for Training and Research (UNITAR). 


\subsection{Public expenditure}

The National Public Investment System (SNIP), administered by MEF, defines principles, methodology and standards for optimised and efficient public investment, as part of Peru's shift towards a results-based budgeting system - Presupuesto por Resultados (PpR) (OECD, 2015). Emphasis on the increased transparency of public budget is another commendable achievement of Peruvian government, allowing tracking public spending on a variety of issues, and the relative prioritisation of different spending categories. For instance, biodiversity-related public spending features in a number of PpR categories, such as '0035 sustainable management of natural resources and biological diversity', '0057 conservation of biological diversity and sustainable use of natural resources in protected natural areas' and ' 0130 competitiveness and sustainable use of forest resources and wildlife'.

Nevertheless, as a share of the total national budget, public expenditure on biodiversity conservation and sustainable use has been low, accounting for around $0.2 \%$ in 2010-2016 (Figure 2.2), while overall environmental spending amounts to around $2 \%$ in the same period. As an example, the National Protected Areas System (SERNANP) has an estimated annual deficit of around PEN 115 million (CARETAS, 2015), compared to its annual budget of PEN 59 million in the last 5 years (MINAM, 2016c) (Box 5). This can be explained by the fact that environmental protection and public spending on environment, including biodiversity, was traditionally viewed as a barrier, rather than opportunity for economic growth in Peru (MINAM, 2016b).

Several environmental funds have been created but tend to also have limited funding. Under the Law on the Creation of the Contingency Fund for Environmental Remediation (Law 30321, 2015), MINEM is authorised to make transfers to the National Fund of the Environment (FONAM) amounting to a maximum of PEN 30 million. ${ }^{13}$ Companies may also make contributions to the FONAM. For instance, the mining companies Buenaventura, Yanacocha, and Goldfields donated PEN 3 million to remediate the impacts from their activities in the Hualgayoc province (World Bank, 2016). The Contingency Fund for Environmental Remediation has a modest budget of PEN 50 million which is disproportionate to its ambitious mission. The Fund was established to remediate the damage caused by oil pollution, after a major environmental controversy involving the direct dumping of by-product water into the Amazonian rivers of Pastaza, Tigre, Corrientes and Marañón, since the 1970s (Defensoría del Pueblo., 2015).

The low level of public investment can be further explained by the lack of implementable projects that can be successful in budget allocation decisions, which are guided by feasibility studies and cost-benefit analyses. There is also a degree of disconnection between the policy planning led by CEPLAN and public investment decision-making effectuated by MEF. Given that biodiversity projects do not always have readily available and easily measurable outcome and impact indicators, it is often difficult for public agencies to effectively bid for biodiversity funding. Therefore, even if biodiversity might be mainstreamed in national strategies, this may not always immediately translate into implementation.

13 Exceptionally in 2015, OEFA was authorised to make an additional transfer to FONAM up to PEN 20 million from the environmental fines levied (Law 30321, 2015). 
Figure 2.2. Biodiversity-related public spending, 2012-2016

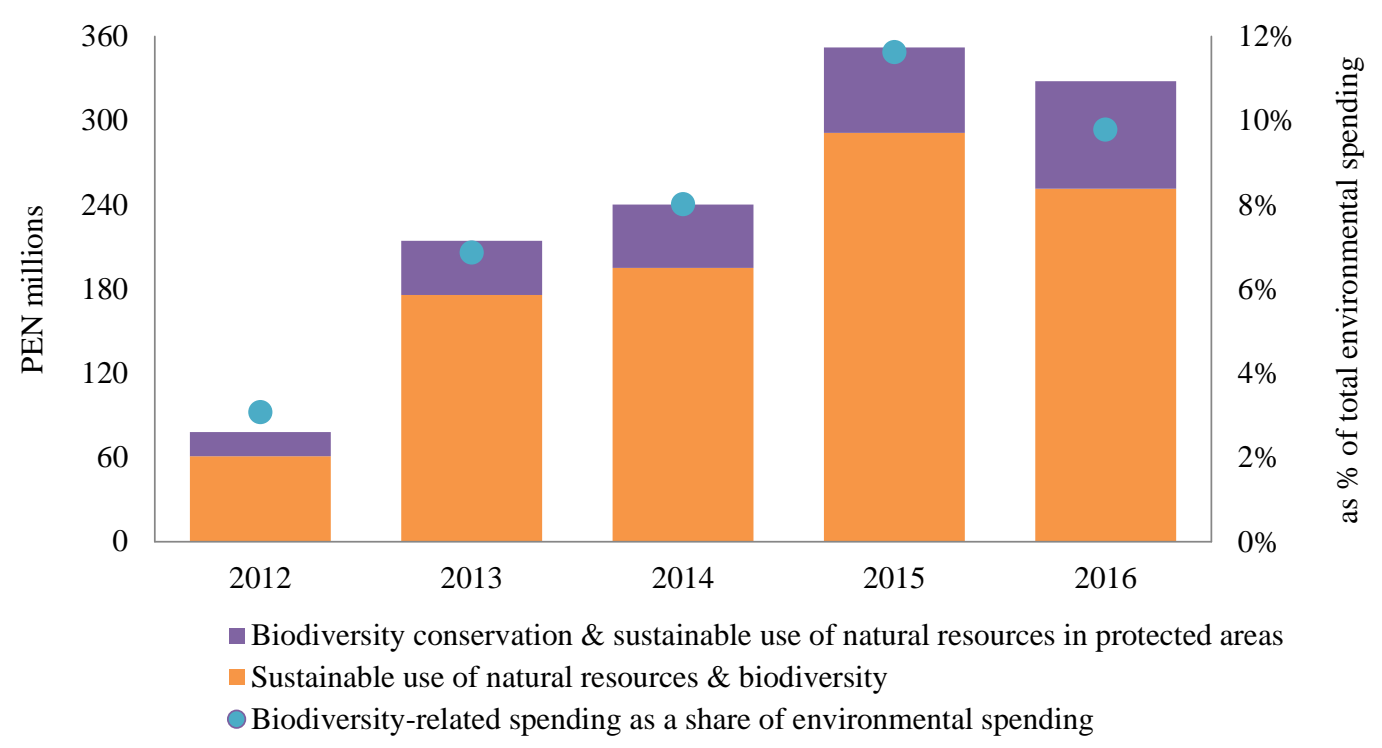

Source: Authors, based on the data retrieved from the Portal of Economic Transparency of the Ministry of Finance and Economy (accessed 23 April 2017).

In recognition of this situation, the government has made efforts to improve guidance on biodiversity public investment projects. MINAM in co-operation with MEF has developed Policy Guidelines for Public Investment in Biodiversity and Ecosystem Services (MEF, 2015a; MINAM, 2015a). The guidelines aim to facilitate public investment in biodiversity conservation and sustainable use, by formulating biodiversity specific requirements that need to be taken into account by public agencies when applying for funding (BIOFIN, 2015). In addition, the Ministry of Economy and Finance developed a set of Standards for Public Investment Projects in Biodiversity and Ecosystem Services to further elaborate the process of public investment in biodiversity (MEF, 2015b; BIOFIN, 2015).

These guidelines seek to improve the bankability of public investment projects (PIP) that aim to conserve and sustainably use biodiversity and ecosystem services - the so-called PIP Verde. It is expected that an increased focus of public expenditure on PIP Verde will contribute to developing an environmental know-how within MEF and, subsequently, foster biodiversity-friendly public investment. The first PIP Verde to meet the guidelines was approved in San Martin, with a budget of PEN 46.5 million. It aims to restore ecosystem services and control soil erosion in the Cumbaza river basin (Proambiente, 2016a).

Further, MEF's approval of the new framework for public investment in 2016 - General Guidelines for Public Investment Projects - gave another strong signal of the increasing recognition of the importance to mobilise finance for biodiversity and ecosystem services (MEF, 2016). The Guidelines state as one of their objectives to promote public investment projects that aim at generating capital in tourism and culture, conservation, restoration and sustainable use of biodiversity and ecosystem services, as drivers for development" (BIOFIN, 2016).

Besides budget allocations, efforts are being made to mobilise public and private investment through a number of economic instruments. An important milestone is the adoption of the Law on the Compensation Mechanism for Ecosystem Services and 
supporting regulations (Law 30215), which provide a legal framework to guide the implementation of PES initiatives. Peru's experience in PES schemes started in 2004 with a project in Moyobamba in San Martín, which introduced a fee for drinking water, used to conserve and sustainably use forests to protect Rumiyacu, Mishquiyacu and Almendra micro-basins.

The success of this initiative paved the way to a number of PES schemes emerging across the country, and leading to the government realising the need to establish a normative framework for these activities (Conveagro, 2014). The PNCBMCC is one of the on-going PES initiatives with a goal to protect 54 million ha of tropical forest. The aim is to build capacity of sub-national governments to conserve forest and support local communities in creating sustainable production systems that can both create income and conserve forest (Wieland Fernandini and Sousa, 2015).

Another instrument to channel finance to biodiversity is the 'works for tax' (obras por impuestos) scheme (Law 29230). The mechanism, which originally did not focus on environment-related issues, is now being extended to include such projects (MINAM, 2016b). The scheme allows companies to undertake public investment projects, as selected by regional or local governments, in return for a tax relief for a maximum value of $50 \%$ of their income tax liability.

\section{Box 5. Funding protected areas in Peru}

While SINANPE experiences a significant budget deficit, funding for protected areas that account for $17 \%$ of national territory, has seen a significant increase over the past years, with a five-fold rise between 2004 and 2010. SINANPE has also diversified its finance sources, with over a fifth of its annual budget coming from the revenues generated by protected areas themselves, mainly through various entrance and user fees ${ }^{14}$. The number of visitors to protected areas has seen an average annual growth of 17\%, more than doubling between 2009 and 2015 (MINAM, 2016c).

The Fund for Promoting Natural Protected Areas (PROFONANPE) is also an important partner of SINANPE. PROFNANPE has mobilised in its over two-decade history a total of USD 151 million from international and national sources, supporting 46 of 77 protected areas (Hickman, 2015; MINAM, 2016c).

REDD+ projects are also becoming an increasingly important source of revenue for protected areas. Currently, projects to conserve more than 2 million ha of primary forest are undertaken in four protected areas - Cordillera Azul National Park, Bahuaja Sonene National Park, Tambopata National Reserve and Alto Mayo Protection Forest. By 2015, Verified Emission Reductions amounted to 10.9 million tCO2, preventing a deforestation of 30000 ha (MINAM, 2016c).

${ }^{14}$ Only a handful of protected areas, such as the well-established tourist destinations Machu Picchu, Islands System, Paracas and Huascarán are able to generate most of their income themselves. 


\section{Mainstreaming biodiversity at sector level}

\subsection{Agriculture}

Agriculture is an important sector for the Peruvian economy, accounting for $25 \%$ of employment (INEI, 2016) and contributing 5.3\% to GDP in 2015 (BCRP, 2017). Peru has extremely rich agro-biodiversity, including two staple crops for human nutrition -maize and potato- and over 180 native domesticated plant species. Indigenous peoples who hold extensive knowledge of the Peruvian genetic resource diversity are essential for conservation and sustainable use of the country's agro-biodiversity (OECD/ECLAC, 2017).

Export-oriented commercial agriculture has experienced a remarkable increase over the past decades, led by the expansion of coffee as a dominant traditional crop ${ }^{15}$, and more recently by exports in non-traditional products (Figure 3.1). In 2015, agriculture products accounted for nearly $15 \%$ of exports, with the majority $(12.8 \%)$ coming from nontraditional crops (BCRP, 2017). Peru has also become a leading exporter of quinoa and asparagus (Oxford Business Group, 2016).

At the same time, agriculture also constitutes a key pressure on biodiversity and forests in Peru. Agriculture activities take up around 38.7 million hectares or $30 \%$ of the territory (OECD/ECLAC, 2017). Up to 90\% of the occurring deforestation can be traced back to the expansion of agricultural frontier (OECD/ECLAC, 2017). The increasing production of crops that are identified as key triggers of deforestation in the sub-tropics, besides coffee, are also cacao, oil palm and coca (Box 6) (Figure 3.2).

\footnotetext{
${ }^{15}$ Recently, export revenues from coffee have seen a decline, as a result of weak prices and disease,
} e.g. the Roya plague (Oxford Business Group, 2016). 
Figure 3.1. Non-traditional and coffee exports, 1990-2015

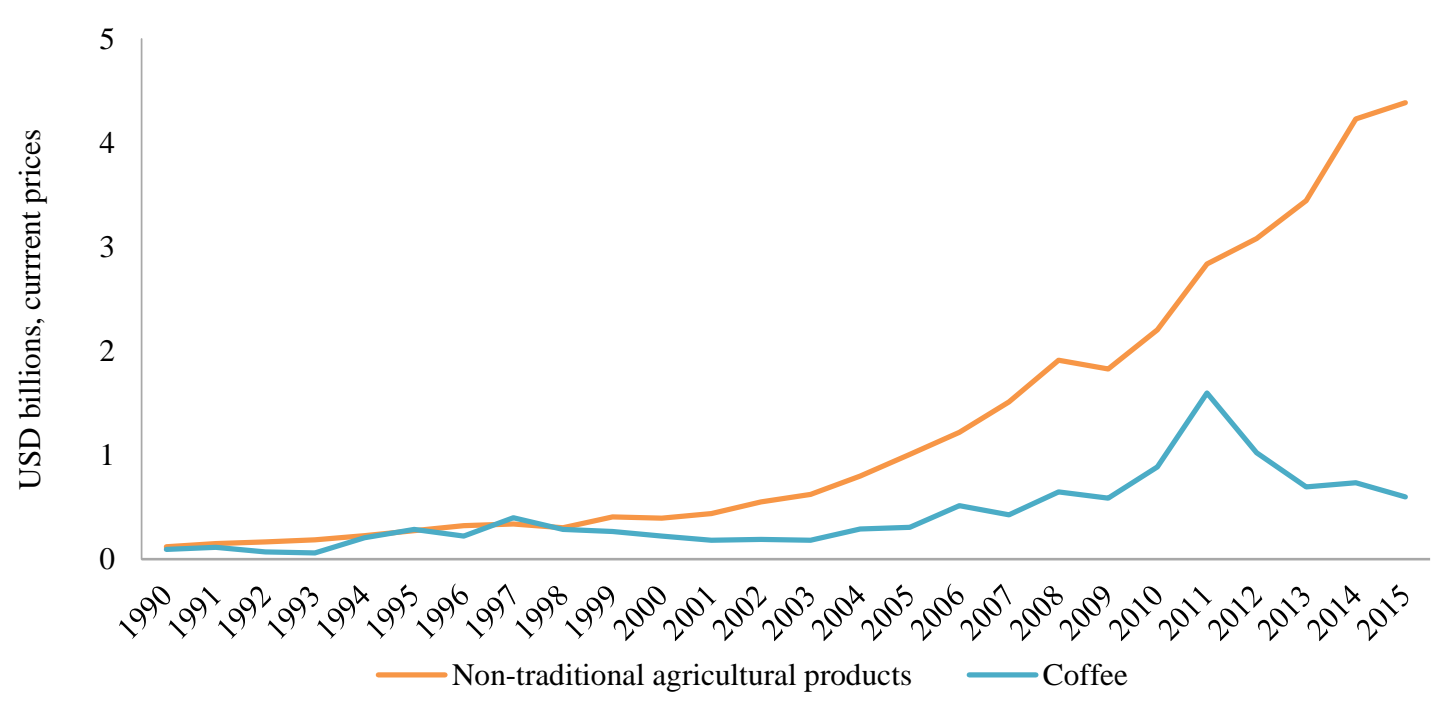

Source: Authors, based on the data retrieved from the Statistics website of the Central Reserve Bank of Peru (accessed 27 May 2016).

Moreover, most non-traditional agriculture exports (e.g. grapes, asparagus and avocado) take place on irrigated coastal lands, which leads to a number of environmental problems. For instance, it has been estimated that the cultivation of water-intensive crops, such as rice, on the coast has caused soil salinisation of 300000 ha, or around $40 \%$ of the agriculture land in Peru's Coastal Valleys (FAO and ITPS, 2015).

\section{Lack of legal land tenure is an important source of deforestation caused by land-use change}

One of the main underlying causes for deforestation is the lack of legal land tenure. Less than $29 \%$ of farmers possess a land title, while the rest rent, invade, or farm communal lands (OECD/ECLAC, 2017). Out of the total of 63 million ha of communal land ${ }^{16}$ in Peru, $42.5 \%$ is occupied by farmers and native communities without property rights (IBC 2016).

A large share of over $30 \%$ of the country's total forest cover represents the so-called unclassified forest area, which is effectively outside any legal and administrative control ${ }^{17}$ (MINAM, 2011b; MINAG 2012; USAID 2014a). These forests are particularly vulnerable to various unregulated activities leading to deforestation, such as land speculation, invasion and agricultural expansion. Land informality also often results in farming activities taking place in the areas with scarce water resources or areas which, according to land capability classification, should be subject to forest and watershed protection.

\footnotetext{
${ }^{16}$ Communal land refers to the land occupied by farmer communities (comunidades campesinas) or indigenous people (comunidades nativas), with or without a land title.

${ }^{17}$ Two-thirds of the Peruvian forests are formally classified, with the three largest groups being production forests - concessions and reserves (24.4\%), protected area forests (22.2\%) and community title forests (14.5\%) (MINAM, 2011b).
} 


\section{Box 6. Palm oil plantations deforest primary forest and violate the rights of indigenous} communities

In the recent years, a number of complaints were filed by local communities, conservation groups and human rights organisations regarding oil palm companies clearing primary forest, and neglecting customary land rights. An example is an oil palm plantation in Ucayali region managed by Plantaciones de Pucallpa which deforested around 5200 hectares of primary forest between 2013 and 2016.

In response to an official complaint submitted by the indigenous community of Santa Clara in Uchunya, the Roundtable on Sustainable Palm Oil - an international palm oil certification organisation concluded that these operations were in breach of its principles. Furthermore, investigations by the Ministry of Agriculture identified that the company had not secured a permit required for forest clearance, and therefore, a suspension order was issued. In 2016, Pucallpa announced that it discontinued all palm oil related activities and exited the palm oil industry (RSPO, 2017).

\section{Majority of coca is cultivated for illegal drug production}

Peru is among top coca cultivating countries in the world, coming second only to Colombia in 2013-14 (Guardian, 2015). Coca is widely cultivated for illegal drug production, making Peru one of the largest cocaine producers in the world - in 2014 less than $10 \%$ of the total $100840 \mathrm{mt}$ dry coca leaf was produced for traditional consumption. This can be explained by a vast price differential. An average price of dry coca leaf was USD 4.3 per kg in 2014, compared to an average price of cocaine of USD 1178 per kg (UNODC, 2016).

Government has undertaken significant eradication efforts, including crop substitution, to contain the expansion of coca cultivation and reduce the area currently under cultivation (UNODC, 2016). During the last two government administrations between January 2012 and June 2017 - the term of President Humala and President Kuczynski PEN 2.1 billion was dedicated to the implementation of an anti-drug policy - reduction of illicit drug trafficking, prevention and treatment of drug consumption, and integrated management and effective drug control (Gómez et al, 2017). Coca cultivation has indeed started to decline from the peak of 62500 ha in 2011, to 40300 ha in 2015 - the lowest level in 15 years (UNODC, 2016). However, in 2016 a new increase of $9 \%$ was recorded, and albeit the lowest growth in the region, it brought the total cultivation area to 43900 ha (UNODC, 2017). 
Figure 3.2. Increase in cultivated area of cacao, coffee and palm oil, 1990-2015

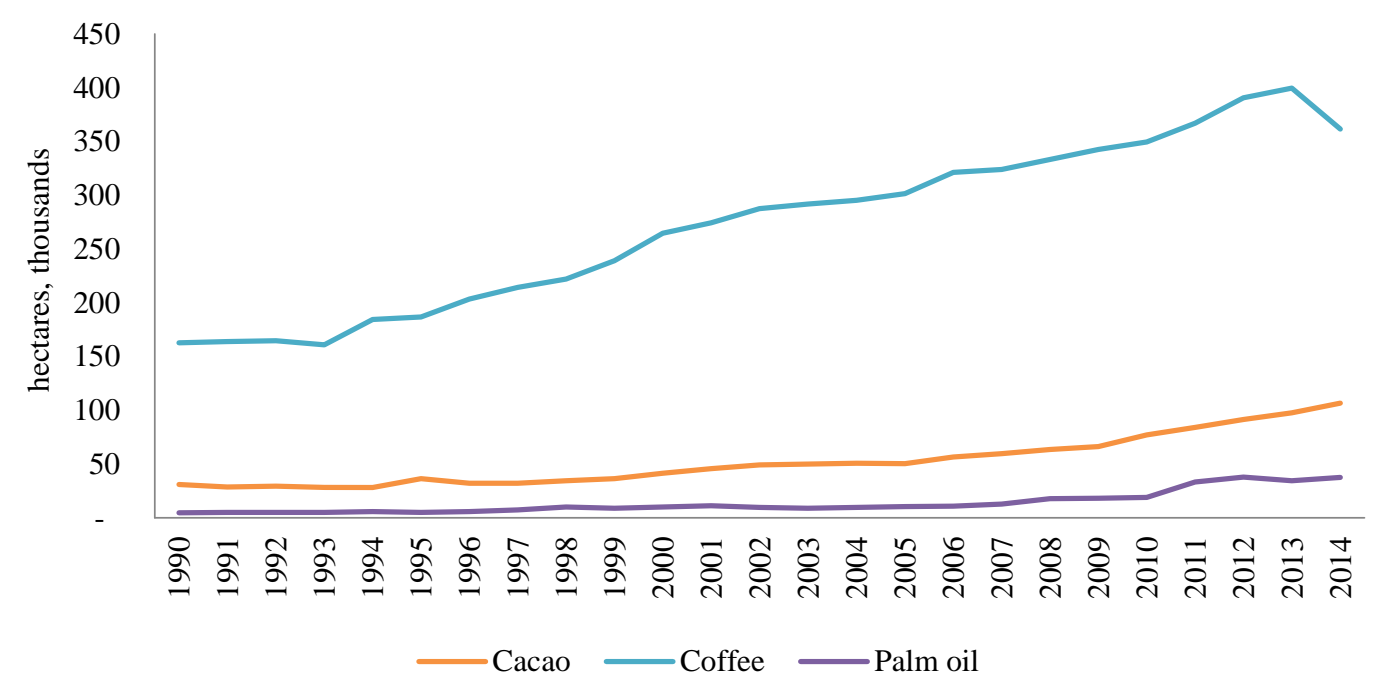

Source: Authors, based on the data retrieved from the website of the Ministry of Agriculture (accessed 27 May 2016).

\section{Various instruments are in use to promote sustainable biodiversity-friendly agriculture}

Peru has recently formulated Nationally Appropriate Mitigation Actions (NAMA) for coffee, cocoa and palm oil, and livestock, applying restoration of degraded areas principles in order to promote sustainable agricultural practices avoid deforestation and soil degradation. For instance, 8000 hectares of degraded land have been devoted to agroforestry cocoa activities, under SERNANP management agreements framework, aiming to facilitate the recovery and sustainable forest management in Madre de Dios and San Martín. Over 650 agreements were signed to promote good soil management practices in protected areas and buffer zones, particularly in Cordillera Azul National Park and Alto Mayo Protected Forest (MINAM, 2016c).

Efforts are also being made to promote conservation of Peru's rich agro-biodiversity. In 2016, Supreme Decree 020-2016-MINAGRI was adopted which approves the regulations formally recognising agro-biodiversity zones, aimed at the conservation and sustainable use of native species cultivated by indigenous peoples.

However, without a clear policy support and economic incentives, such as Payments for Agro-biodiversity Conservation Services (PACS), farmers tend to see little value in conservation activities or are simply unable to afford them (Biodiversity International, 2015). A pilot PES scheme targeting smallholder farmers cultivating quinoa varieties has shown that such incentives can be both cost-effective and yield a positive impact on poor households (FAO, 2013).

Recognising the challenges associate with attributing the correct value to agro-biodiversity, MINAM in collaboration with Biodiversity International launched a Rewards for Agrobiodiversity Conservation Services (ReSCA) programme. The initiative constitutes an innovative mechanism that aims to capture the total value of agro-biodiversity and conserve native genetic resources. ReSCA rewards communities that have for generations cultivated 
native agro-biodiversity crops. In 2015, conservation and sustainable use contracts were signed with six communities (Santa María, Sihuayro, Lacasia, Huataquita, Huaytahuancho and Macaya Piripirini) involved in growing quinoa. The communities committed to cultivating seeds of five native quinoa cultivars at risk of extinction, which have good adaptive capacity to climate change and extreme weather conditions, such as droughts and frost, as well as to diseases. As a result, their conservation constitutes a food security priority (MINAM, 2016d, 2015b). Another important initiative is the Project for Strategic Development of Natural Resources (PRODERN), supported by the Belgian Development Co-operation, and forming part of the government strategic orientation to achieve inclusive economic growth and alleviate poverty in remote rural areas. As one of its key objectives, PRODERN seeks to address negative impact on biodiversity as a result of deforestation, harmful agricultural practices, ineffective land management and loss of ancestral knowledge (PRODERN, 2018).

SERNANP has also concluded a management agreement with Conservation International to guide their partnership in Alto Mayo Protected Forest to promote organic coffee production and certification, with an aim to reduce deforestation and improve farmers' income. With 90000 certified hectares, Peru is a leading global exporter of organic coffee, mostly grown by smallholder farmers (USDA, 2017). As a result of this project, 200 families received an organic coffee certification in 2015. This is the first such certification granted within a protected area in Peru, which enables the farmers to access international markets for organic coffee (Conservation International, 2018; MINAM, 2016b).

\subsection{Forestry}

\section{Commercial forestry sector falls short of its potential and illegal logging prevails}

Illegal logging, that is often associated with biodiversity loss, accounts for $80 \%$ of Peru's total timber exports (Goncalves et al., 2012), while the potential of formal forestry sector remains significantly under-exploited (OECD, 2016a). Forestry contributes less than $1 \%$ to GDP and employs $1.6 \%$ of population, of which only $0.4 \%$ is in the formal sector (FAO, 2014). Furthermore, given low levels of value addition and industrialisation, Peru is a net importer of forest products, with the trade deficit widening over time.

In view of this, PRODUCE's National Productive Diversification Plan (2014) identifies the development of the forestry sector as a priority to reduce the country's dependence on raw materials. In the wake of the consultations and formulation of the plan, the government has announced its objective to double forestry exports by 2017. By 2021, the exports should reach USD 3 billion, while timber imports would be halved. At the same time, 2 million ha of land are envisaged to be re-forested (Oxford Business Group, 2016).

Access to credit is one of the main bottlenecks for the development of the sector. Banks have so far been reluctant to provide long-term loans for forestry, while reforestation projects tend to take 8-10 years (Andina, 2015).The government has sought to ease financing constraints through the new Forestry and Wildlife Law that recognises plantations as crops allowing a better access to public and private financing (OECD, 2016a).

As the government advances its forestry policy, it is important to ensure that forest resources are managed sustainably, and the expansion of the productive sector does not occur at the expense of sustainability. In July 2016, Peru approved the National Forestry and Climate Change Strategy, which was a combined effort by MINAM, national agencies, 
regional governments, the civil society and indigenous peoples. The document identifies key risks to forests in Peru and proposes measures to address these. The proposed solutions include a 'production-protection approach' which seeks to increase landscape productivity, while achieving forest conservation. This echoes the 'productive conservation' principle for biodiversity and ecosystems advocated by the NBSAP.

Currently, 37\% of Peru's total forest area is under forest management plans (FMP), as one of the FAO indicators of sustainable forest management (SFM) (FAO, 2016). However, only $2 \%$ of FMP in Peru is annually monitored (FAO, 2015). Furthermore, only $5 \%$ of total production forest is certified under an international scheme, such as Forest Stewardship Council (FAO, 2015). While there are signs that FSC has had a positive impact on environmental management, main barriers for companies to engage in and implement certification include the lack of financial resources and capacity, limited productive diversification and access to markets for certified timber, and high informality of the sector. All these factors relate back to the need to develop a formal and sustainably managed forestry sector (Trujillo, 2014).

Linking certification schemes to green public procurement in large infrastructure projects at regional and national level is also useful tool to create a domestic market for certified timber and promote the development of a sustainable forestry sector. For instance, the green public procurement programme led by the Cooperation Fund for Social Development (FONCODES) in collaboration with SERFOR and the Ministry of Education launched a pilot project to acquire FSC-certified timber for school furniture (GIZ, 2016; WWF, 2014). There are plans to extend this programme to the Ministry of Housing.

\subsection{Fishery}

Peru has one of the most productive seas in the world, accounting for over $6 \%$ of the global catch (OECD/ECLAC, 2017). The General Law on Fisheries (Law 25977, 1992) regulates fishing activities depending on the purpose of extraction (e.g., commercial vs subsistence), the scale (e.g. small-scale, artisanal vs large-scale), and other factors. The biggest single species is the anchovy, accounting for $86 \%$ of the catch, which has traditionally been used for fishmeal and fish oil. Mackerel and squid are also fished. Non-traditional exports have expanded significantly over the last years, led by frozen seafood and canned products (Figure 3.3).

Key pressures on marine ecosystems in Peru include overfishing, by-catch, environmentally harmful fishing methods and pollution. The management of marine resources remains predominantly sector based, driven by commercial considerations focused on anchovy production, as opposed to an ecosystem approach. Marine ecosystems are also subject to relatively weaker environmental protection - marine protected areas cover less than $4 \%$ of territorial waters, which is significantly below the regional and OECD average (OECD/ECLAC, 2017). 
Figure 3.3. Increase in exports of traditional and non-traditional fish products, 1990-2015

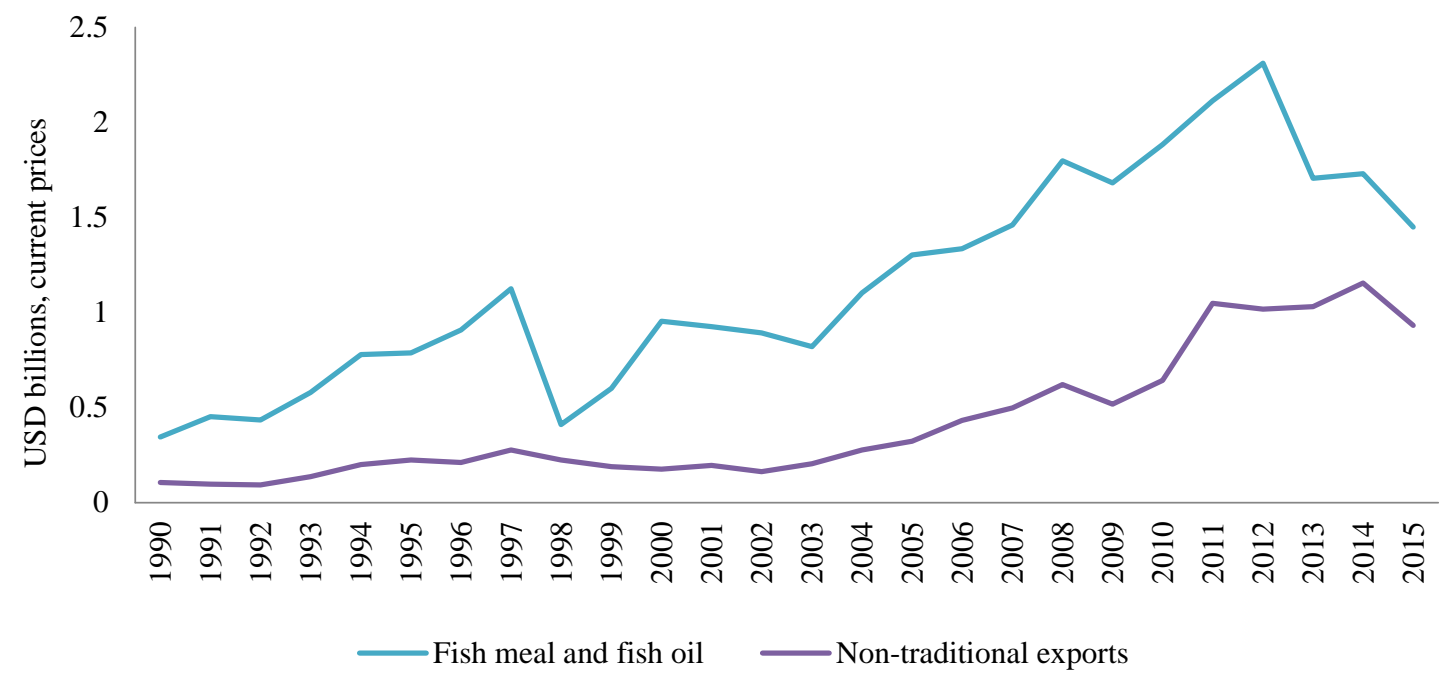

Source: Authors, based on the data retrieved from the Statistics website of the Central Reserve Bank of Peru (accessed 27 May 2016).

\section{Several policy instruments have been introduced to restore anchovy population - but progress is needed in other fisheries}

In the early 1980s, the anchovy industry collapsed as a result of unregulated extraction and the El Niño (Guy, 2016). In response, Peru adopted a number of legal instruments.

As part of the General Law on Fisheries, PRODUCE is responsible for managing all fisheries and aquaculture activities in Peru, and may create fisheries management regulations (ROP - Reglamentos de Ordenamiento Pesquero). ROPs establish such restrictions as such as access regimes, fishing seasons, total allowable catch, fishing gear requirements, minimum size requirements or designated fishing areas. However, according to a David and Lucile Packard Foundation study (2014), there were only nine ROPs in place in 2014, covering seven species, while 35\% of the most important commercial species are subject to no regulations.

Virtually all anchovy production is covered by Friends of the Sea (FOS) certification, accounting for $29 \%$ of certified seafood production worldwide (Potts et al., 2016). ${ }^{18}$

\section{Individual vessel quotas}

In 2009, PRODUCE introduced an individual vessel quota (IVQ) system for the Peruvian anchovy, financed by taxes levied on fishing companies. The system establishes regulations over minimum size, fishing season limits and quotas (Young and Lankester, 2013). The scientific basis for the IVQ system is provided by the IMPARPE. The IVQ scheme is considered widely successful in reducing overcapacity and more than doubling the length of the fishing season since its launch (Tveteras et. al., 2011).

${ }^{18}$ Certification is also emerging for aquaculture, for instance, through the Aquaculture Stewardship Council. However, it remains a very small proportion of total aquaculture production in Peru (Potts et al., 2016). 
Furthermore, the IVQ has generated over USD 10 million for the social fund FONCOPES, contributed by programme participants based on the amount of a quota per vessel and crew size (Galarza, 2010). FONCOPES has supported fishermen voluntary retirement and labour transition schemes (Young and Lankester, 2013).

\section{Remaining challenges}

Despite the success of IVQ, it is only a single measure while there is still a need for a comprehensive management plan for anchovy fishing. Such a plan would also provide for coordinated approach to managing joint stock with Chile. Conservation plans are also required for other fish species however, since beyond anchovies, no catch quotas are in place (OECD/ECLAC, 2017).

Furthermore, there is limited policy coherence on marine issues overall, as responsibilities for managing marine resources are dispersed across institutions. While the Commission of Environmental Management of the Coastal Marine Medium (COMUMA) established in 2012 is responsible for co-ordination and has much potential, effectiveness is significantly undermined by inadequate institutional representation and seniority. Overall, surveillance efforts should also be increased to eradicate illegal fishing and to formalise informal fishing activities (OECD/ECLAC, 2017), and further efforts are needed to address pollution, from e.g. fishmeal plants. For example, environmental NGOs have frequently highlighted the occurrences of negative local social and ecological impacts. These include complaints raised from local artisanal fisheries on the scarcity of important commercial species of fish and shellfish, including due to water pollution by the discharge from fishmeal plants (Majluf, 2006).

\subsection{Extractive sector}

\section{The expansion of the mining sector raises environment concerns, triggering social unrest}

Mining has historically been an important sector for the Peruvian economy, driven by the exports of copper and gold, and periodically oil, silver, lead and zinc. Following a debt crisis in the 1980s, the revival of international trade coupled with Fujimori's liberal structural reforms, privatisation and lax taxation in the 1990s, served as a powerful boost to the extractives sector. In 2015, mining and hydrocarbons contributed $12 \%$ to GDP and accounted for $62 \%$ of total exports (Figure 3.4). 
Figure 3.4. Mining and hydrocarbons as percentage of exports and GDP, 1950-2015

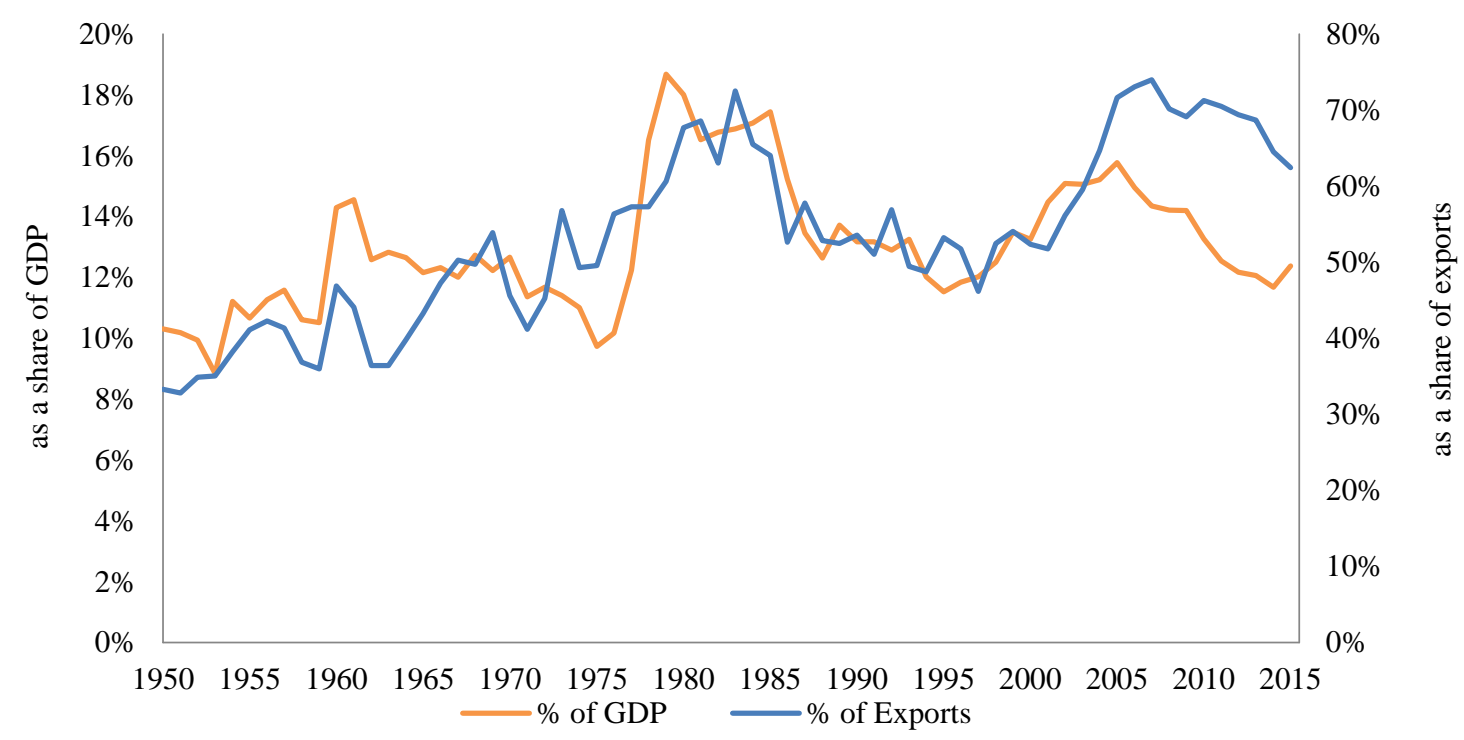

Source: Authors, based on the data retrieved from the Statistics website of the Central Reserve Bank of Peru (accessed 7 October 2016).

The expansion of the extractives sector has raised environmental and health concerns, sparking social unrest. Deforestation and mercury pollution are among the most common problems associated with mining activities, including informal and illegal mining (Box 7) (MINAM, 2014c). Monthly Reports on Social Conflicts ${ }^{19}$ by the Office of the Ombudsperson show that socio-environmental conflicts are fundamentally driven by the extractive sector. For instance, the controversy over the potential harmful impacts of the Conga gold mine project on water resources escalated to the extent of a government crisis in 2011. During his first months in the office, the newly elected President Humala was forced to declare a state of emergency (Walton, 2016).

${ }^{19}$ Reporte Mensual de Conflictos Sociales. They are available online on the website of the Office of the Ombudsperson (Defensoría del Pueblo). 


\section{Box 7. Illicit gold mining poses a major risk to biodiversity and erodes government revenues}

Illicit mining activities ${ }^{20}$ are widespread in Peru - it is estimated that 21 out of 25 regions are subject to illegal or informal mining, which directly employs around 100000 people, with a total of 400000 being involved indirectly (Korinek, 2015). Illegal activities tend to be concentrated in gold mining, driven by a 360\% surge in gold prices, in the decade following the financial crisis (de Queiroz et al., 2014).

Income from illegal and informal gold mining reached 1.8 billion in 2012, surpassing that from drug trafficking (Korinek, 2015). In the regions most affected, e.g. Madre de Dios and Piura, informal and illegal activities create more jobs and income than the formal sector (Korinek, 2015).

Besides government revenue erosion, illicit mining is associated with high risks both for ecosystems and human health, by driving deforestation and pollution. In Madre de Dios, illegal and informal mining is destroying annually around 1915 ha of tropical forest (Swenson et al., 2011; SPDA, 2012). Furthermore, over the past 20 years, more than 3 000 metric tons of mercury have been disposed into the Amazonian rivers, causing water contamination, affecting both ecosystems and human health (Korinek, 2015).

It is important to note that efforts to improve infrastructure, for instance the construction of Inter-Oceanic Highway in Madre de Dios, tend to support illicit activities, facilitating access and connectivity (de Queiroz et al., 2014). It is thus essential to bear this in mind when designing and assessing the impact of prospective infrastructure projects.

\section{Progress made in strengthening institutions and regulatory instruments to mainstream biodiversity partly reversed by new law promoting investment in mining}

\section{Transfer of responsibility for detailed EIAs to SENACE}

Environmental impact assessments (EIA) are the single most important policy instrument in place in Peru to regulate environmental impacts of the mining sector (Box 1). In the past, the responsibility to conduct and review EIAs lay with sector authorities. For instance, MINEM was responsible for EIAs in the mining and energy sectors. Such an arrangement often triggered concerns whether environmental considerations were sufficiently respected, given a potential conflict of interest between pursuing sector growth and protecting the environment (Castro et al., 2014).

In response, the government has launched an extensive EIA reform, which envisages an extensive transfer of responsibilities for environmental certification for large-scale projects that require detailed EIAs from sector authorities to the National Service of Certification for Sustainable Investment (SENACE). The transfer has started with the mining and energy sectors, and is being phased-in gradually throughout the rest of the economy (Chapter 2).

${ }^{20}$ The Peruvian legal system (Supreme Decree No. 014-92-EM of June 1992) differentiates between two types of illicit mining activities. Illegal mining denotes the extraction of mineral resources from concession areas belonging to someone else, while informal mining refers to the extraction of resources from areas with no concession. 
Among the challenges faced by SENACE is to accumulate adequate technical know-how across the various sectors, and build its regulatory and administrative capacity. It is not planned that SENACE would absorb respective units previously responsible for environmental affairs within ministries, such as the Directorates of Environmental Affairs in the MINEM's Vice-Ministries of Mining and Energy.

Furthermore, the regulations passed for the SEIA Law require EIAs to incorporate a valuation of natural heritage, including biodiversity and ecosystem (Chapter 2). Moreover, in 2016 the government issued Guidance on Biodiversity Offsets, with a focus on Andean ecosystems. The document sets out the methodology for assessing biodiversity losses and gains, and developing offset schemes for mining, hydropower and other infrastructure activities (Jenkins et al., 2016). These changes pose an additional demand to build the public service capacity. In order to support regional offices in reviewing EIAs, MINAM had by 2010 trained more than 100 officials in 12 regions. In 2010-2011, USD 1 million was set aside to build capacity in ecosystem valuations of 1350 officials in 25 regions (Bovarnick et al., 2010).

\section{Development of Strategic Environmental Assessment}

In addition to EIAs conducted for individual projects, Strategic Environmental Assessment (SEA) is a useful regulatory instrument to evaluate environmental implications of policies, plans and strategies at national, regional and local level. SEA became part of SEIA Law by 1078 Legislative Decree in 2008 (Barandiarán 2008). In preparation of the regulation in 2008, a pilot was carried out for the Northern Inter-oceanic Road linking Paita and Yurimaguas ports. However, further use of SEA has been limited, given a lack of implementation guidelines.

In response, MINAM has undertaken efforts to improve capacity to implement SEAs. In 2015, MINAM hosted a training course on SEA for the staff of different ministries and affiliated agencies, seeking to strengthen civil servants' capacity to use SEA in policy formulation (MINAM, 2015c). In 2016, MINAM approved the first SEA, proposed by the regional government of Loreto for its Regional Concerted Development Plan (PDRC) 2021 (Regional Government of Loreto, 2016).

SENACE's mandate is complemented by the Environmental Assessment and Oversight Agency (OEFA), which is undergoing a similar transfer of functions from sector authorities. OEFA is responsible for conducting environmental audit and impose fines on companies, if they do not comply with prescribed environmental standards. With the creation of OEFA in 2008, the enforcement of environmental regulation has shown a sign of improvement. The environmental fines collected reached its peak of nearly PEN 66 million in 2013 (Figure 3.5). However, in practice, fines do not have a clear link to actual economic costs associated with environmental damages, caused by a mining activity (OECD/ECLAC, 2017).

\section{New law weakens MINAM's and OEFA's supervisory powers}

The improvements achieved in environmental enforcement saw a partial reversal in 2014 when the Law 30230 was adopted in an effort to promote investment in the mining sector, in response to the global economic downturn. The Law significantly limits MINAM's mandate to set environmental standards for soil, water and air quality. The value of fines has been considerably reduced and the period to conduct environmental studies limited to 45 days, affecting the thoroughness of such assessments (KPMG, 2016). Furthermore, OEFA can impose fines only if designated corrective measures have not been carried out. 
As a potential consequence, 2015 featured a sharp decline in the level of environmental fines collected (Figure 3.5).

A report by the Office of the Ombudsperson published in 2015 explicitly called for Congress to revoke the measure (Defensoría del Pueblo, 2015). The report identified that the number of environmental liabilities caused by mining activities reached 8600 by 2015, of which nearly half are classified as high or very high risk. However, the vast majority (88\%) of environmental liabilities did not have a responsible party identified. ${ }^{21}$ Furthermore, in cases where a responsible party was identified, fines were imposed only on a fraction of companies. In 2010-2012, four mining companies were fined out of the total of 224 which did not have an environmental study conducted. Human rights and indigenous organisations also expressed their concern in a public hearing in January 2017 before the Constitutional Tribunal in Arequipa, arguing that the law is unconstitutional.

Figure 3.5. Mining industry’s environmental fines, 2007-2015

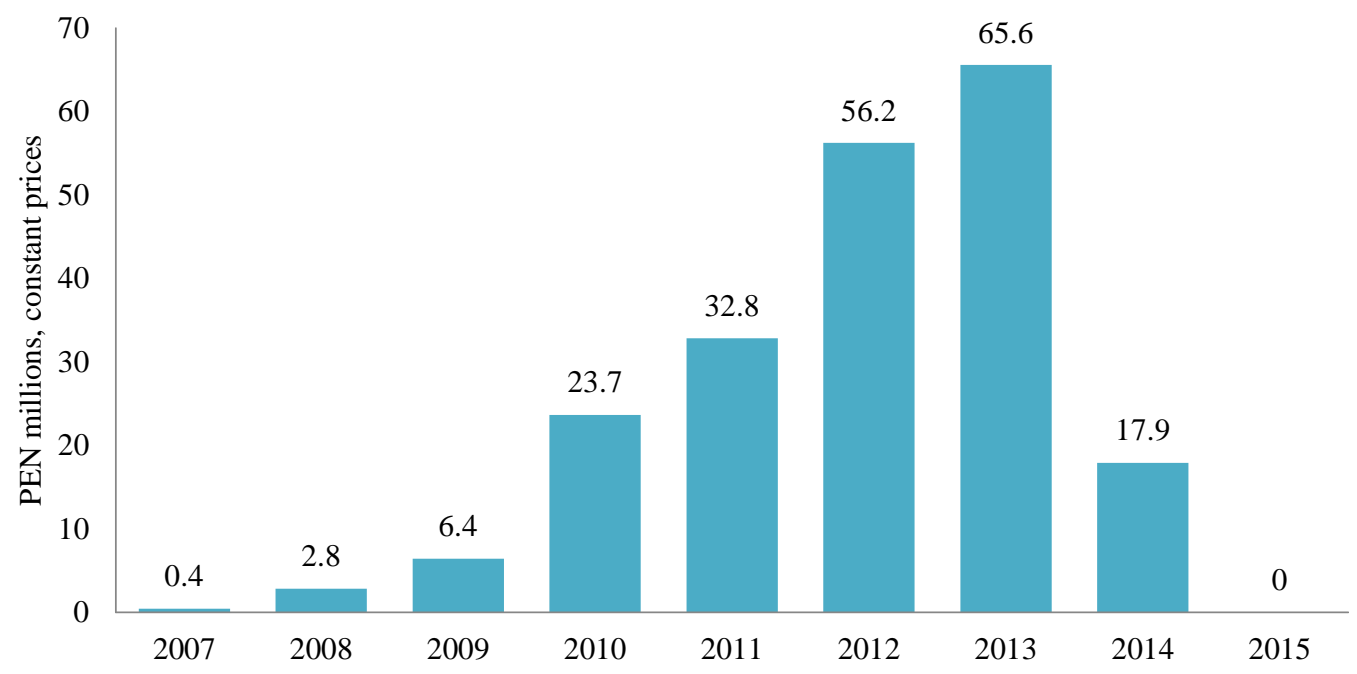

Source: Orihuela and Paredes (2017).

\section{Mining is a major source of government revenues, but only a minor share is re- invested in biodiversity conservation and communities}

While Peru has extensive environmental legislation, there is a clear understanding that EIAs alone are not sufficient to mainstream biodiversity. The policy framework is dominated by command-and-control measures with little use of economic instruments (Castro et al., 2014; OECD-ECLAC, 2017). There are no specific environmental taxes levied on the mining sector, while a limited share of fiscal revenues are earmarked to be re-invested in the communities affected by mining.

Mining and hydrocarbon activities generate significant government revenues (Figure 3.6), a large share of which is transferred to sub-national authorities where resources are extracted. These can be used to finance public investment projects, including the provision of basic services. However, there is no explicit requirement for sub-national governments

21 The information on environmental fines on mining companies became publicly available after the period that MINEM was no longer the regulator during the tenure of OSINERGMIN (Dammert and Mollinelli, 2007). 
to reinvest the corporate income tax proceeds which represent the vast majority of fiscal revenues from mining into communities affected by mining activities (Korinek, 2015). On the contrary, $10 \%$ of total royalties must be spent on the communities where resources are extracted.

Figure 3.6. Mining and hydrocarbons as a share of fiscal revenues, 2000-2014

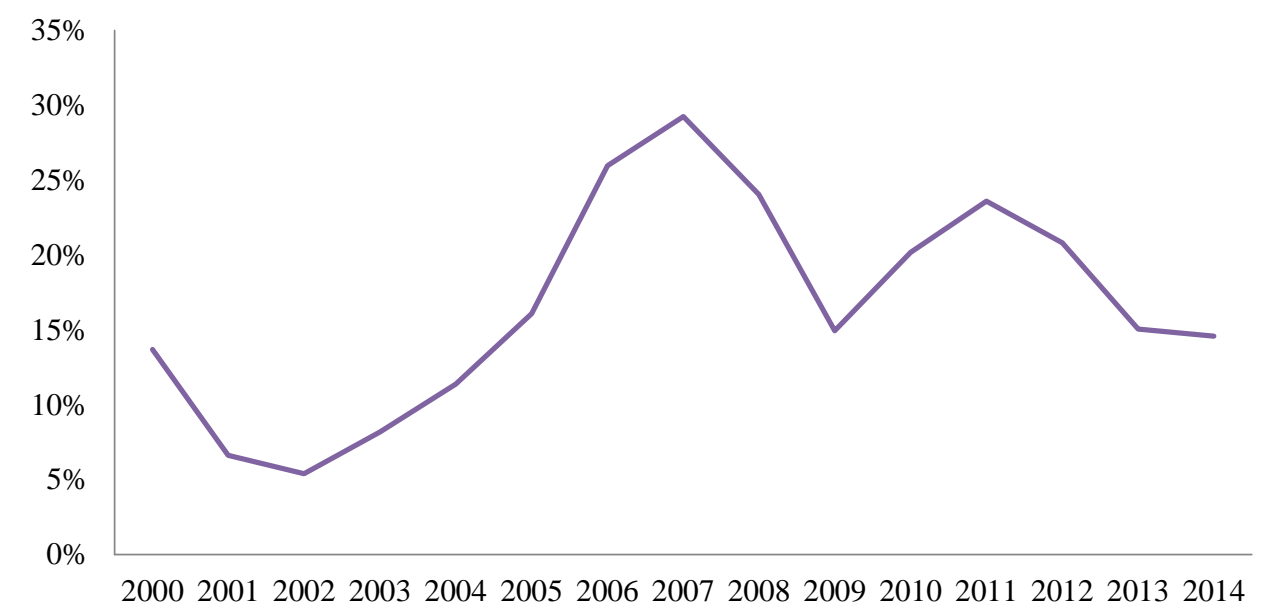

Source: Authors, based on the data retrieved from the website of the National Superintendency of Customs and Tax Administration (SUNAT) (accessed 1 October 2016).

Furthermore, the current revenue distribution arrangement is highly skewed, and may create significant inter-regional inequality. For instance, over the last decade, the region of Ancash received by far the largest share of total sub-national transfers, followed by a handful of other regions (Figure 3.7). At the same time, Madre de Dios that is one of the regions experiencing the most severe ecological impacts of the mining sector has received a fraction of total transfers. This may in part be explained by a large scale of illegal gold mining activities in Madre de Dios. Moreover, regions and provinces which are in close proximity to the areas where mining activities take place but are not formally mining concession areas would not benefit from the tax revenues, while may still be affected by the environmental damage (Korinek, 2015). 
Figure 3.7. Sub-national transfers of corporate income tax, cumulative 2005-2014

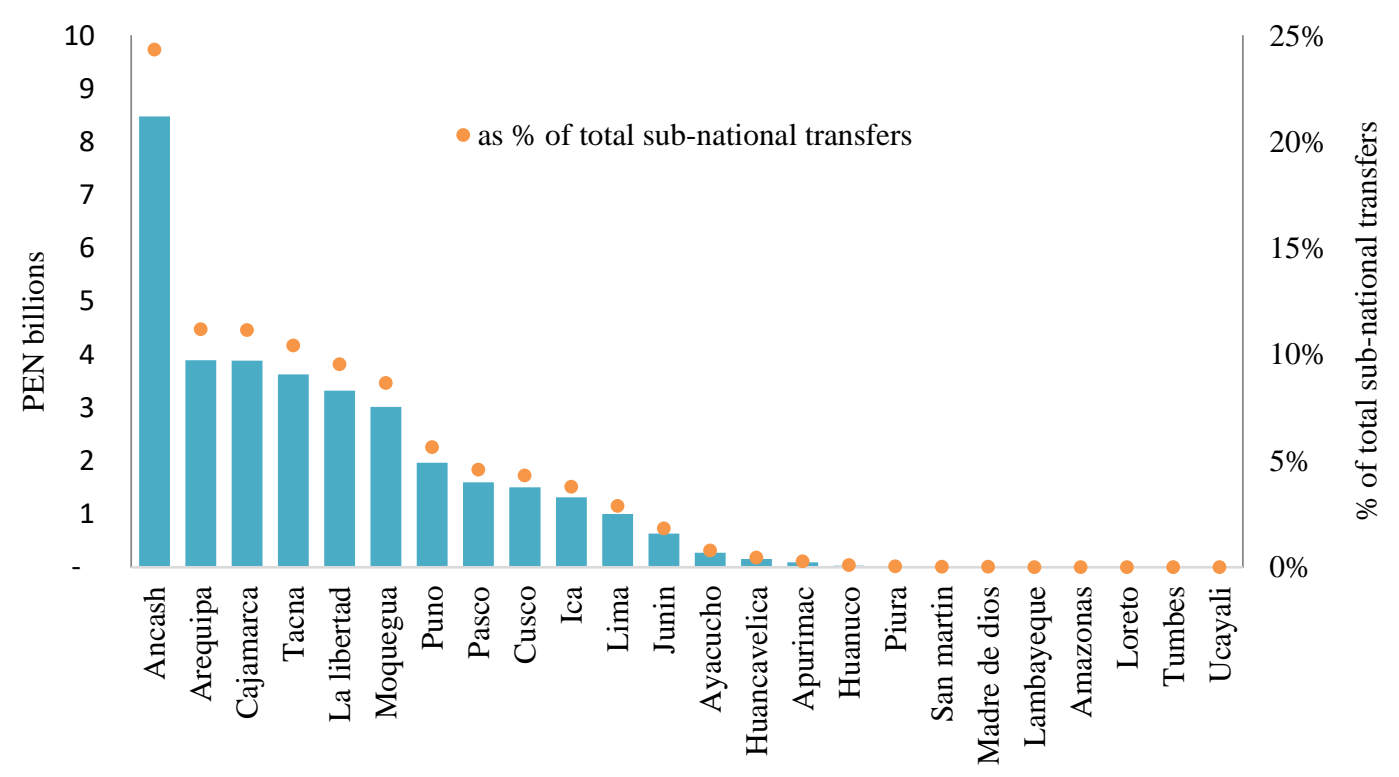

Source: Authors, based on the data retrieved from the website of the Ministry of Economy and Finance (accessed 27 May 2016).

Efforts are emerging to integrate biodiversity into private sector business models

In an effort to mainstream biodiversity concerns in the business models of companies operating in the sectors that have the potential to significantly affect environment, MINAM, in co-operation with development partners, launched in 2014 a Biodiversity and Business initiative. The initiative covers all major sectors, such as mining (e.g. Antamina), energy (CLEPSA, LNG Peru), tourism (Rainforest Expeditions), fisheries (TASA) and forestry (Maderacre). Companies work in four thematic groups: public economic instruments for conservation; information management; tools and guidelines of good socio-environmental practices; and in situ conservation of biodiversity. As part of the work stream on economic instruments, a number of proposals for tax incentives have been developed; for instance, $50 \%$ income tax credit on investment into environmental projects (MINAM, 2015d). However, the initiative remains predominantly government-led. For its further development and effectiveness, it is important to continue to secure greater private sector buy-in and support from key business leaders. 


\section{Development co-operation support to mainstreaming}

\subsection{Development finance and assistance in key policy areas}

With Peru transitioning to an upper middle-income economy over the past decade, the development co-operation landscape has been changing (USAID, 2012). Amongst the changes has been a shift away from poverty reduction activities towards a greater emphasis on environmental objectives in development finance portfolios. This is evident in the share of Official Development Assistance (ODA) commitments channelled by the members of the OECD Development Assistance Committee (DAC) ${ }^{22}$ towards environment-related activities, including biodiversity, which saw a nearly five-fold increase from USD 71.0 million in 2006-07, to USD 334.8 million in 2014-15 per year in Peru (Figures 4.1; 4.2).

\section{Figure 4.1. Focus on environment-related objectives in bilateral ODA in Peru}

Two-year averages

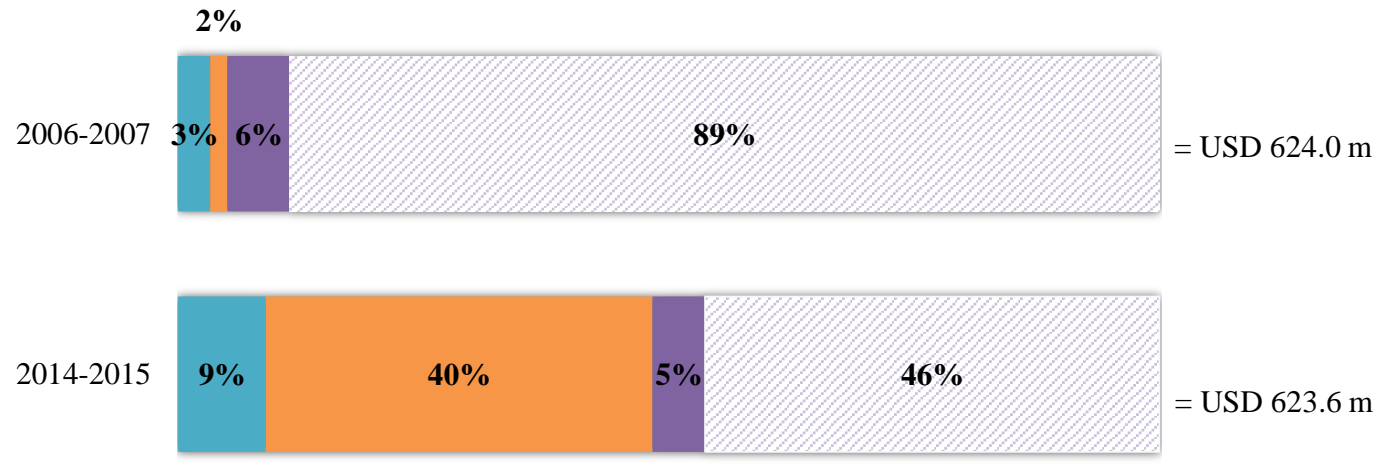

\footnotetext{
- Biodiversity

- Other Rio Convetions (climate change \& desertification)

- Other environmental objectives

Non-environmental objectives
}

Source: Authors, based on the data retrieved from OECD DAC Creditor Reporting System, stats.oecd.org (accessed 15 November 2016).

Note: 'Biodiversity' includes both activities targeting biodiversity only and those that simultaneously target the objectives of the Rio Conventions. 'Other Rio conventions' includes activities that do not target biodiversity.

This development has created a strong momentum to advance work also on biodiversity. Biodiversity-related bilateral ODA has more than doubled over the same period, reaching

${ }^{22}$ Over the past decade, half of total development finance to Peru came from multilateral providers. Non-concessional Other Official Flows (OOF) from bilateral and multilateral providers accounted for nearly two thirds of development finance. This flyer focuses on bilateral ODA by DAC members, given that reporting on biodiversity-related multilateral development finance and non-concessional Other Official Flows (OOF) to the DAC CRS is currently partial. Further, it focuses on bilateral ODA earmarked for Peru. This does not include regional initiatives or other activities for which a country has not been specified in the CRS. 
USD 55.6 million per year in 2014-2015, representing 9\% of total ODA commitments (Figure 4.2). The top five providers - Germany, the US, Belgium, Spain and the EU account for $92 \%$ of this ODA.

At the same time, the national-level data ${ }^{23}$ may mask significant regional disparities. From a review of the projects focusing on a specific geographic area, rather than the national level, ODA portfolios tend to target marine and mountain ecosystems relatively less compared to the Amazon basin. In view of this, continued efforts of development cooperation providers in support of biodiversity in the Andes and Coast are particularly noteworthy. For example, the Swiss Development Co-operation's (SDC) Andean programme has committed CHF 2 million between 2012 and 2017 to Peru and other countries in the region. The programme aims to improve sustainable management of water resources in the Andean Mountains, given climate change-related risks (SDC, 2018). Furthermore, the Capacities for Biodiversity and Sustainable Development (CEBioS) programme by the Royal Belgian Institute of Natural Sciences (RBINS) provided support to IMARPE, to strengthen its capacity to monitor and manage vulnerable marine ecosystems in Peru (CEBioS, 2018).

Figure 4.2. Bilateral biodiversity-related ODA in Peru, 2006-2015

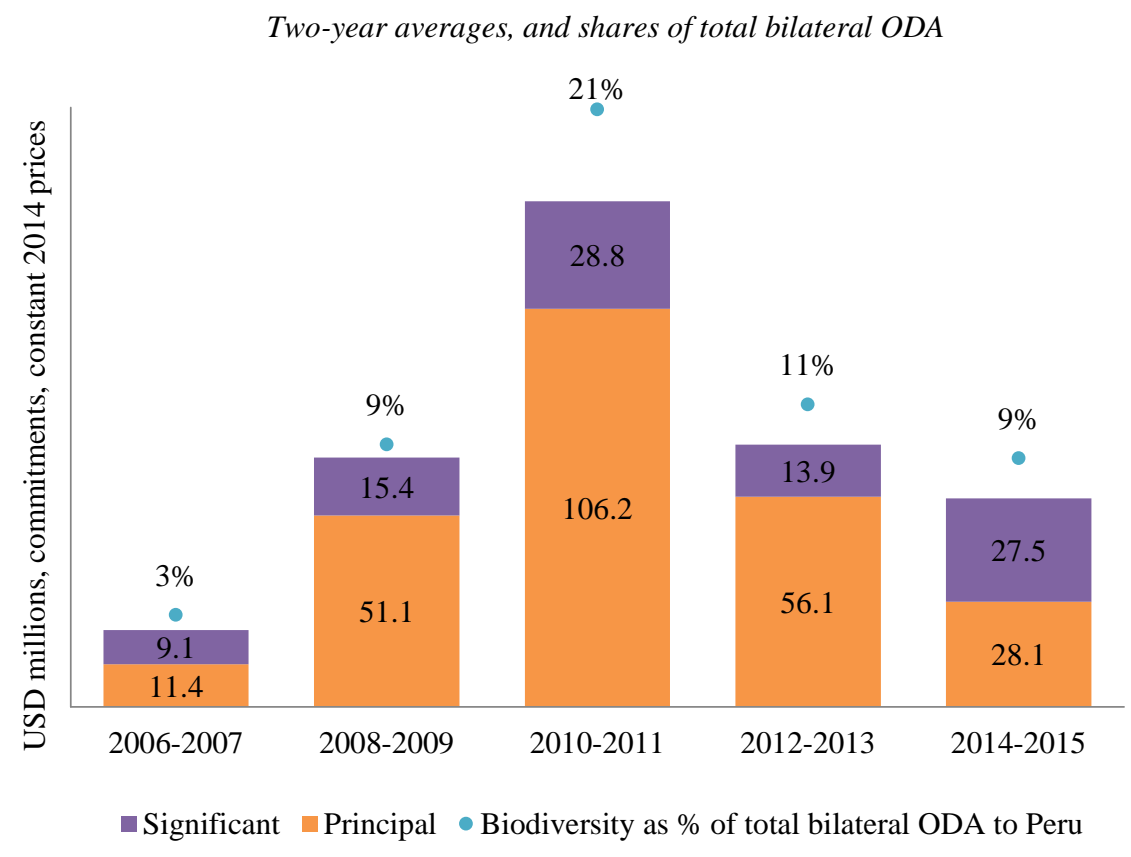

Source: Authors, based on the data retrieved from OECD DAC Creditor Reporting System, stats.oecd.org (accessed 15 November 2016).

\footnotetext{
${ }^{23}$ Based on the OECD DAC CRS data, sub-national disaggregation is not easily available. However, despite the lack of relevant sub-national variables, a keyword search across project-level data allows identifying approximate geographical focus of projects. Given that the analysis in this paper is specifically focused on the development co-operation support to improving biodiversity mainstreaming, rather than merely ODA commitments to biodiversity conservation, these data constraints are not expected to substantially affect the analysis.
} 


\section{Development partners support the design of policies and legislation at the national and sub-national level}

Development co-operation actors - bilateral and multilateral - have supported the government to achieve several milestones that have shaped the national institutional and legal landscape for biodiversity mainstreaming. GIZ, through the ProAmbiente programme, has been a key partner of the government in establishing MINAM in 2008. ProAmbiente has also supported the newly created Ministry in developing such central environmental strategies as the National Action Plan for the Environment 2010-2021 (PLANAA). The plan places biodiversity amongst the seven key environmental priority areas for the forthcoming decade, and formulates respective goals and actions (MINAM, 2011c).

Development partners have played an important role in supporting the development of key legislation. GIZ assisted with the work on the design of the Law on Compensation Mechanisms for Ecosystem Services of 2014, which creates a legal foundation for country's PES initiatives, including REDD+. GIZ supported the country's first PES scheme in Moyobamba in San Martín for hydrological services, which set a precedent for future PES projects and paved the way to the adoption of the Law (Conveagro, 2014) (Chapter 2). The USAID has supported the government throughout the process of developing and adopting the landmark Forestry and Wildlife Law in 2011, and the Peruvian Forest and Wildlife National Policy in 2013 (USAID, 2014a) (Chapter 2).

Donors have also assisted with formulating policies and strategies at the sub-national level. The USAID supported Puno region in the development of its Action Plan for the Regional Biodiversity Strategy, as part of the Initiative for Conservation in the Andean Amazon (ICAA). Loreto was supported in creating the Regional Environmental Agency, and developing regional environmental plans for protected areas, forest management, and the fishing sector (USAID, 2016a). In Piura, GIZ launched a pilot project for integrating ecosystem services into development planning and public investment, with a focus on land management and combating desertification (GIZ, 2015). The UNDP also works with regional governments on biodiversity strategies and regional development plans.

\section{Development finance and technical assistance are supporting the implementation of policy instruments}

Development co-operation has also assisted the government in implementing specific policy instruments, for instance, providing finance to some of the largest PES schemes. The Japanese Government, through Japan International Cooperation Agency (JICA) and the Hatoyama Initiative, committed USD 40 million to the PNCBMCC. PNCBMCC, led by MINAM, has a goal of conserving 54 million ha of tropical forest, by providing economic incentives for conservation. In 2014, a Joint Declaration of Intent on REDD+ was signed between the Governments of Peru, Norway and Germany. As part of the agreement, Norway committed USD 300 million for a three-phase programme ${ }^{24}$ set to run until 2020 for verified results in reducing forest-related carbon emissions. Germany agreed to continue, and potentially expand, its already extensive climate change support to Peru. On

24 First two phases, 2014-2015 and 2015-2017, focus on the implementation of REDD+ core elements, and key institutional reforms. During this time, Peru is expected amongst others, to get the land-use conversion from forest to agriculture under control. The final phase 2017-2020, will see the disbursement of funds for verified results in reducing emissions. 
its part, Peru seeks to render its forestry and agriculture sectors carbon neutral by 2021 and make a significant progress in recognising land claims of indigenous peoples.

Development co-operation assistance has also been important for building capacity to implement the policy instruments in place. This is particularly important at sub-national level where, as discussed above, technical expertise is often limited. USAID has adopted a technical assistance programme (PAT) with MINAM aimed to support Ministry's directorates in a number of projects (MINAM, 2018). These include promoting the integration of economic valuation in environmental policy making (PAT Valoración); improving co-ordination between the three tiers of government and developing standards for the operationalisation of SEIA (PAT SEIA); and training regional government officials for improved conservation and sustainable management of forests (PAT Bosques).

\section{Support to improving data and information is an enabler of mainstreaming}

Filling the gaps in data and information collection through improved technical expertise and technology is also an area where development community has closely engaged with the government in Peru. The UNDP BIOFIN initiative has conducted a Biodiversity Expenditure Review, assessing the level of biodiversity spending from both national and international, and public and private sources. UNDP is also conducting a Biodiversity Finance Needs Assessment to estimate the cost of implementing the NBTs, and corresponding activities under the NBSAP (UNDP Peru, 2016).

To support Peru in its efforts to combat deforestation by sharing, amongst others, the Japanese satellite technology and technical expertise to monitor forest cover, JICA has launched a technical cooperation programme with MINAM (Goseki, 2014; MINAM, 2015e). As part of the USAID Sustainable Conservation Approaches in Priority Ecosystems (SCAPES) project, technical assistance was provided to SERNANP to use the Spatial Monitoring and Reporting Tool (SMART) tool. SMART allows SERNANP to enhance the management effectiveness of protected areas, by improving measuring, monitoring and evaluation of the effectiveness of wildlife law enforcement patrols (USAID, 2013). SMART is now recognised as a central tool of information management in SINANPE (USAID, 2016a).

\subsection{Remaining challenges}

\section{Efforts to promote private sector engagement are underway, yet more needs to be done}

Development co-operation can significantly contribute to an enhanced private sector engagement. GIZ and SECO have joined forces with national and regional actors, including universities, to develop a pilot PerúBioInnova initiative. The Initiative seeks to promote green start-ups and expand bio-trade in Peru (ProAmbiente, 2016b). A number of international partners ${ }^{25}$ have also offered a joint support to the Peru National BioTrade Promotion Programme (PNPB), developed and approved by CONAM in 2004 prior to the creation of MINAM. PNPB is led by MINCETUR in co-operation with MINAM, PRODUCE and other public and private sector institutions (PromPeru, 2014). PNPB aims to support local businesses in developing biodiversity product value chains, and improve the access of these products to international markets.

\footnotetext{
${ }^{25}$ CAN, CAF, GEF, UNEP, UNCTAD, SECO and GIZ
} 
While some concrete measures have been undertaken to improve private sector engagement, more needs to be done. One of the potential channels is continued work with the companies that are part of the Biodiversity and Business initiative to ensure strong private sector buy-in and leadership (Chapter 3).

\section{Collaboration between development partners, and with the government, should be strengthened}

Development activities can also benefit inter-ministerial co-ordination. For instance, embedding GIZ advisors into the government ministries offices has been deemed important in facilitating horizontal work streams between MINAM and other ministries, particularly MEF. FAO's work with MINAGRI's SERFOR and MINAM on sustainable forest management also contributes to strengthening the dialogue on environmental issues between the agriculture and forestry sectors.

Furthermore, strengthened collaboration is essential also for securing government buy-in in development co-operation programmes, including through better policy prioritisation and budget allocation, to ensure longevity of positive impacts achieved beyond the lifetime of a specific project. This challenge is not unique to the Peruvian policy context, representing a key area requiring increased consideration for several development cooperation providers and their partner countries (OECD, 2018 forthcoming).

The ability to collaborate between development partners is equally important for the effectiveness of development co-operation. There are different forms of dialogue, including regular inter-agency meetings of an environmental institutionalised donor round-table. The round-table, in which government ministries (e.g. MINAM, MINAGRI, MINEM) are also present, serves as a platform for development partners to exchange updates on their respective projects, seeking to increase complementarity and avoid duplication. There are also examples of successful partnering on project financing and implementation. For instance, UNDP BIOFIN and GIZ ProAmbiente have worked together to support MINAM and MEF in formulating Guidelines for Public Investment in Biodiversity and Ecosystem Services (BIOFIN, 2015).

However, closer co-ordination between donors is needed to further improve the effectiveness of development co-operation in Peru. There are still cases when biodiversityrelated development activities are conducted in silos, increasing the risk of duplication. Better co-ordinated development co-operation has a stronger potential to also bring together different parts and tiers of the government for better mainstreaming.

\section{New instruments need to be exploited to scale up development finance for biodiversity}

As part of the changes in development co-operation, there has also been a shift away from grants towards concessional loans as the preferred development aid instrument, with the share of grants declining from $86 \%$ in 2006-07, to 64\% in 2014-15. However, when it comes to biodiversity activities, grants continue to account for nearly all bilateral ODA, except for 2009-2011, when large concessional loans were provided by Japan and Germany. ${ }^{26}$

There is thus potential to explore greater variety in biodiversity finance instruments within and beyond ODA. Finding new catalytic good practice approaches to using external

\footnotetext{
${ }^{26}$ Based on the data from the OECD DAC Creditor Reporting System (CRS), as of November 2016.
} 
resources to scale-up domestic finance, including leveraging green private investment, is key to effective development co-operation in the domain of biodiversity mainstreaming in Peru (Crishna Morgado and Lasfargues, 2017).

\section{Importance of harnessing synergies between biodiversity and other development activities is recognised, but scope for more sector mainstreaming remains}

There are clear signs that the providers of ODA in support of biodiversity in Peru recognise the importance of exploiting the co-benefits of biodiversity objectives with other development activities. Nearly half of bilateral biodiversity-related ODA has a main priority other than biodiversity. Biodiversity is essentially mainstreamed into these activities, being targeted as a secondary objective ${ }^{27}$. An example of a good practice to promote biodiversity activities within ODA portfolios is the USAID's Peru country strategy for 2012-2016, which that places a strong emphasis on biodiversity. The strategy pledges $80 \%$ of overall environmental funding to forest- related sustainable landscapes and biodiversity programmes in the Amazon Basin (USAID, 2012). Similarly, GIZ ProAmbiente has sustainable forest management and biodiversity innovation as two of its four core priorities.

However, when looking at biodiversity as a share of total bilateral ODA to sectors, there is a varying level of mainstreaming, signalling further potential for a number of sectors (Figure 4.3). For instance, in the agriculture sector, despite it being one of the top sectors attracting biodiversity-related ODA, biodiversity activities account for $22 \%$ as a total aid to the sector. At the same time, in the fishing sector, nearly all ODA supports biodiversityrelated objectives. In contrast, the mining sector which has a high impact on biodiversity (Chapter 4), receives only $0.2 \%$ (USD 0.13 million on average per year) of bilateral biodiversity-related ODA.

It is important to continue to harness the synergies between biodiversity and other environmental and developmental priorities across all sectors for two main reasons. First, it will help integrate biodiversity angle thinking into all development activities, including other environment projects. For instance, concerns have been raised that biodiversity has not been sufficiently integrated in climate change discussions in Peru (Piu and Menton, 2014). Second, exploiting co-benefits will help raise more finance for biodiversity to close the funding gap, discussed in Chapter 2 .

To support this process and break silos between different development themes in their portfolios, development partners can develop guidelines for mainstreaming and reporting on biodiversity-related components within all projects and activities. For instance, USAID has formulated a comprehensive package for integrating biodiversity in its development projects (Box 8). Improving co-ordination between capitals and in-country missions are equally important factors in ensuring effective biodiversity mainstreaming.

${ }^{27}$ This is based on the OECD DAC Rio marker methodology (see Annex): 49\% (USD 27.5 million) of biodiversity-related ODA in 2014-15 had biodiversity as a secondary objective, while 51\% (USD 28.1 million) targeted biodiversity as a primary or 'principal' objective, meaning that these activities would not have been funded but for their biodiversity-related goals. 


\section{Box 8. USAID comprehensive biodiversity policy package guides mainstreaming in practice}

USAID policy package in support of mainstreaming biodiversity includes Biodiversity Policy (USAID, 2014b), complemented by a Biodiversity and Development Handbook (USAID, 2015b) which provides practitioners with a step-by-step guide on integrating biodiversity projects in different sectors, outlining the main programming and policy linkages.

Further, USAID developed Biodiversity and Development Research Agenda, with an aim to build the evidence base for synergies between biodiversity conservation and development objectives, such as economic growth, food security, health, governance, and gender equality (USAID, 2015c). Finally, there are three Biodiversity How-To Guides which provide detailed guidance to practitioners on the design and management of biodiversity programmes in accordance with the policy (USAID, 2016b).

Figure 4.3. Mainstreaming in top sectors receiving biodiversity-related ODA in Peru

Biodiversity as a share of total bilateral ODA to sector, 2014-2015 average

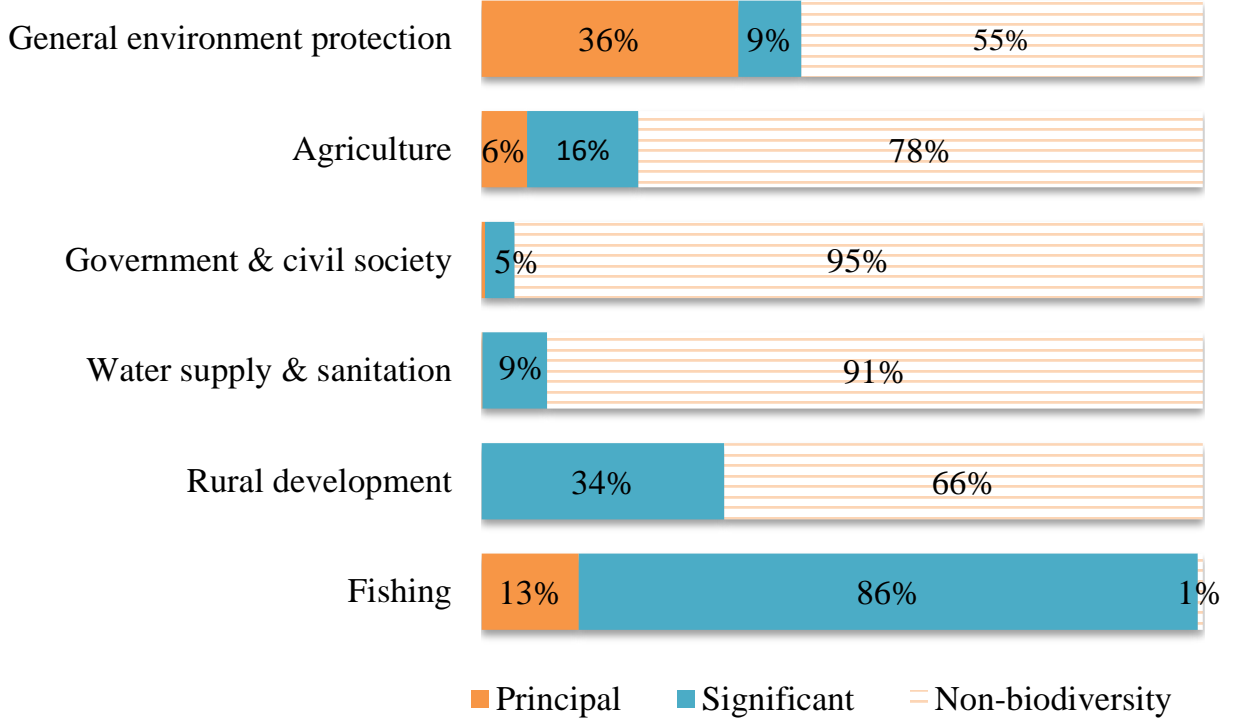

Source: Authors, based on the data retrieved from OECD DAC Creditor Reporting System, stats.oecd.org (accessed 15 November 2016). 


\section{References}

Andina (2015), Peru: Diversification Plan boosts forestry investments, www.andina.com.pe/ingles/noticia-peru-diversification-plan-boosts-forestry-investments589864.aspx

BCRP (2017), Statistics of the Central Reserve Bank of Peru (BCRP), http://www.bcrp.gob.pe/estadisticas (accessed 30 January 2017).

Biodiversity International (2015), Incentives to conserve agricultural biodiversity - Peru at the forefront, 15 May, www.bioversityinternational.org/news/detail/incentives-to-conserve-agriculturalbiodiversity-peru-at-the-forefront/

BIOFIN (2016), 'Peru achieves new milestone, incorporating biodiversity in general investment policy', Biodiversity Finance Initiative News, 5 August, www.biodiversityfinance.net/news/peru-achievesnew-milestone-incorporating-biodiversity-general-investment-policy (accessed 30 March 2017)

BIOFIN (2015), “Peru: One Step Ahead on Biodiversity Finance”, Biodiversity Finance Initiative News, 8 September, www.biodiversityfinance.net/news/peru-one-step-ahead-biodiversity-finance (accessed 13 January 2017)

Bovarnick A, Knight C \& Stephenson J. (2010), Habitat Banking in Peru: A Feasibility Assessment Working Paper. United Nations Development Programme, www.natureservicesperu.com/uploads/3/1/7/4/3174185/pwc undp_peru.pdf

CARETAS (2015), 'Rumbo a la Sostenibilidad Financiera' in El Año de la Conservación, 11 June, www.sernanp.gob.pe/documents/10181/104923/INF+SERNANP.pdf/71c709ef-b7bb-4fb1-86cbc338d8753336

Castro, M. et al. (2014), 'Environmental impact assessment reform in Peru', 34th Annual Conference of the International Association for Impact Assessment

CEBioS (2018), Capacities for Biodiversity and Sustainable Development website, www.biodiv.be/cebios2/partnerships/institutional/peru, (accessed 15 January 2018)

CEPLAN (2011), Plan Bicentenario: El Perú hacia el 2021, Centro Nacional de Planeamiento estratégico, Lima

COMEX (2014), 'Lo que aportó la minería’, Semanario Sociedad de Comercio Exterior del Perú, 20- 26 January, www.semanariocomexperu.wordpress.com/lo-que-aporto-la-mineria/

CONCYTEC (2015), Programa Nacional Transversal de Ciencia, Tecnología e Innovación Tecnológica de Valoración de la Biodiversidad, 2015 - 2021, Consejo Nacional de Ciencia, Tecnología e Innovación Tecnológica, http://www.cienciactiva.gob.pe/images/documentos/programas.

Conservation International (2018), Café producido en el Bosque de Protección Alto Mayo logra certificación orgánica, 
www.conservation.org/global/peru/Pages/Certificacion_Organica_COOPBAM.aspx (accessed 15 January 2018)

Conservation International (2016), Cuentas Experimentales de los Ecosistemas en San Martín-Perú. Lima: Fundación Conservación Internacional

Conveagro (2014), 'En Perú, se promulga Ley de Mecanismos de Retribución por Servicios Ecosistémicos’, Convención Nacional del Agro Peruano, 1 July, www.conveagro.org.pe/node/10688

Crishna Morgado, N. and B. Lasfargues (2017), "Engaging the private sector for green growth and climate action: An overview of development co-operation efforts", OECD Development Cooperation Working Papers, No. 34, OECD Publishing, Paris.

David and Lucile Packard Foundation (2014), A Marine Conservation Assessment in Peru, December, www.fondationensemble.org/wp-content/uploads/2015/02/ACS-Marine-Conservation-Assessmentof-Peru-final.pdf

Dammert, A. and Molinelli, F. (2007), Panorama de la minería en el Perú. Lima: Osinergmin.

Defensoría del Pueblo (2015), ¡Un Llamado a la Remediación! Avances y Pendientes en la Gestión Estatal Frente a los Pasivos Ambientales Mineros e Hidrocarburíferos. Serie Informes Defensoriales, Informe 171, Lima: DDP

de Queiroz, J. S. et al. (2014), Peru Tropical Forest and Biodiversity Assessment, US Foreign Assistance Act, Section 118/119 Report August, USAID, Washington, DC

EIA (2012), "The laundering machine: How fraud and corruption in Peru's concession system are destroying the future of its forests”, Environmental Investigation Agency, Washington, DC, and London

ENAHO (2015), Población En Situación De Pobreza Monetaria, Según Ámbito Geográfico, 2006 2015, Encuesta Nacional de Hogares, www.inei.gob.pe/estadisticas/indice-tematico/sociales (accessed 31 January 2017)

FAO (2017), The Forest and Landscape Restoration Mechanism (FLRM), Food and Agriculture Organization, www.fao.org/in-action/forest-landscape-restorationmechanism/activities/national/peru/en/ (accessed 30 May 2017)

FAO (2016), Global Forest Resources Assessment 2015: How are the world's forests changing?, Food and Agriculture Organization of the United Nations, second edition, www.fao.org/3/a-i4793e.pdf

FAO (2015), Global Forest Resources Assessment 2015, Desk reference, Food and Agriculture Organization of the United Nations: Rome, www.fao.org/3/a-i4808e.pdf

FAO (2014), State of the World's Forests, Food and Agriculture Organization of the United Nations: Rome, www.fao.org/3/a-i3710e.pdf

FAO (2013), "No free lunches: PES and the funding of agricultural biodiversity conservation Insights from a competitive tender for quinoa-related conservation services in Bolivia and Peru", Case studies on Remuneration of Positive Externalities (RPE)/ Payments for Environmental Services (PES), Prepared for the Multi-stakeholder dialogue 12-13 September 2013, FAO, Rome 
FAO and ITPS (2015), Status of the World's Soil Resources (SWSR) - Main Report, Food and Agriculture Organization of the United Nations and Intergovernmental Technical Panel on Soils, Rome, Italy

FIDH (2009), Peru - Bagua: Bloodshed in the Context of Amazon Protest - Urgent Need for Good Faith Dialogue, International Federation for Human Rights, Paris

Galarza, E. (2010), “Individual Quotas for Anchoveta Fishery in Peru: First Year of Implementation”, Power Point presentation, Lima: CIUP

GEOSERVIDOR (2014), Mapa de análisis de cambio de cobertura de bosques a no bosque por deforestación de la Amazonia Peruana elaborado por el Ministerio del Ambiente, www.geoservidor.minam.gob.pe (accessed 1 July 2016)

GIZ (2016), Promoting sustainable forest management and a competitive forest industry in Peru, ProAmbiente project ProMadera, www.proambiente.org.pe/umwelt/recursos/publicaciones/BrochureProMadera-eng.pdf

GIZ (2015), “A practical approach for integrating ecosystem services into development planning”, GI Peru, www.giz.de/expertise/downloads/giz2015-en-biodiv-ies-piura.pdf

Gómez, D., L. Moreno, M. Sarmiento and J. Martínez (2017), ¿Quién se lleva el dinero del presupuesto antidrogas en el Perú?, 3 June, Ojo Público Narcomapa, www.narcomapa.ojopublico.com/articulo/quien-se-lleva-el-dinero-del-presupuesto-antidrogas-en-el-peru

Goncalves, M. P. et al. (2012), Justice for Forests: Improving Criminal Justice Efforts to Combat Illegal Logging, World Bank, Washington, DC

Goseki, K. (2014), Overview of MINAM-JICA Cooperation: The Project of Capacity Development for Promoting Sustainable Forest Management and REDD+ in Peru, www.mmechanisms.org/cop20_japanpavilion/files/12051300_presentation_2.pdf

Greenspan, E. (2014), “Protestors and UN report test Peru's new indigenous peoples’ consultation law”, The Politics of Poverty, 16 May, Oxfam America, Boston and Washington, DC, http://politicsofpoverty.oxfamamerica.org/2014/05/protestors-un-report-test-peru-new-indigenouspeoples-consultation-law

Greenspan, E. (2011), “Peru’s Congress passes precedent-setting Consultation Law”, The Politics of Poverty, Oxfam America, 2 September, www.politicsofpoverty.oxfamamerica.org/2011/09/perucongress-passes-precedent-setting-consultation-law

Guardian (2015), “Peru coca growers decry insufficient compensation for anti-drug eradication”, 17 August, www.theguardian.com/world/2015/aug/17/peru-coca-plant-growers-eradicationcompensation

Guarín, A. and H. Hotz (2015), Assessing the use of forest ecosystem services analyses as a national policy-making tool in Peru, Global Green Growth Institute, November 
Guy, A. (2016), “Overfishing and El Niño push the world's biggest single species fishery to a critical point”, 2 February, OCEANA

Hickman, A. (2015), “Becoming ‘climate finance ready': Peru’s experience”, Climate \& Development Knowledge Network, 25 May, www.cdkn.org/2015/05/feature-becoming-climate-finance-readyperus-experience/?loclang=en gb

IBC (2016), Tierras comunales: Mas que preservar el pasado es asegurar el futuro. El estado de las comunidades indígenas en el Perú, Informe 2016. Lima: IBC

IDLO (2016), Review of Post-2010 National Biodiversity Strategies and Action Plan: Legal Preparedness for Biodiversity, International Development Law Organisation

IIAP (2018), Instituto de Investigaciones de la Amazonía Peruana, www.iiap.org.pe, (accessed 15 January 2018)

INAIGEM (2018), Instituto Nacional de Investigación en Glaciares y Ecosistemas de Montaña, www.inaigem.gob.pe (accessed 15 January 2018)

INEI (2016), Peru: Evolution of employment and income indicators by department 2004-2015, National Institute of Statistics and Information, Lima

Jenkins, M., G. Gammie, and J. Cassin (2016), “Peru Approves New Innovative Environmental Policies”, Forest Trends, 27 July, www.forest-trends.org/blog/2016/07/27/peru-approves-newinnovative-environmental-policies/

Korinek, J. (2015), "Managing the Minerals Sector: Implications for Trade from Peru and Colombia”, OECD Trade Policy Papers, No. 186, OECD Publishing, Paris, dx.doi.org/10.1787/5jrp6wrc2r7l-en

KPMG (2016), Peru country mining guide, KPMG Global Mining Institute, February, https://assets.kpmg.com/content/dam/kpmg/pdf/2016/03/peru-mining-country-guide.pdf

Machado, R. (2014), “La economía informal en el Perú: magnitud y determinantes (1980-2011)”, Apuntes $74: 197-233$

Majluf, P. (2006), “Mapping traditional fishing areas as a tool for developing proposals for marine protected areas, Punta San Juan, Southern Peru, www.whitleyaward.org/winners/mapping-traditionalfishing-marine-protected-areas-punta-san-juan-peru

MEF (2016), Lineamientos Generales para Proyectos de Inversión Pública, Directorate General of Public Investment, Ministry of Economy and Finance, Lima, Peru www.mef.gob.pe/contenidos/inv_publica/docs/normas/normasv/2016/RD-007-2016EF/LINEAMIENTOS_GENERALES_PARA_PROYECTOS_DE_INVERSION_PUBLICA.pdf

MEF (2015a), Lineamientos de Política de Inversión Pública en materia de Diversidad Biológica y Servicios Ecosistémicos 2015-2021, Ministry of Economy and Finance, Lima, Peru https://www.mef.gob.pe/contenidos/inv_publica/docs/politicas_i/lineamientos/RM-199-2015MINAM.pdf 
MEF (2015b), Lineamientos para la Formulación de Proyectos de inversión pública en Diversidad Biológica y Servicios Ecosistémicos, Directorate General of Public Investment, Ministry of Economy and Finance, Lima, Peru

MINAG (2012), Propuesta Preliminar de Política Nacional Forestal y de Fauna Silvestre, Ministry of Agriculture, Lima

MINAG (2013), Manejo Forestal y de Fauna Silvestre, Ministry of Agriculture, Lima

MINAGRI (2016), Inventario Nacional: El Inventario Nacional Forestal, Ministry of Agriculture, Lima www.minagri.gob.pe/portal/objetivos/462-semana-nacional-forestal/9852-inventario-nacional

MINAM (2018), Programa de Asistencia Técnica - PAT USAID/MINAM, Ministry of Environment, Lima, www.minam.gob.pe/patusaid (accessed 15 January 2018)

MINAM (2017), Proyecto de presupuesto del sector ambiental para el año fiscal 2018: Resumen Ejecutivo, Ministry of Environment, Lima

MINAM (2016a), Estrategia Nacional sobre Bosques y Cambio Climático, Decreto Supremo No. 0072016-MINAM, Ministry of Environment, Lima

MINAM (2016b), Finanzas para la Sostenibilidad 2011-2016: Financing for Environmental Management, Ministry of Environment, Lima, www.minam.gob.pe/informessectoriales/wpcontent/uploads/sites/112/2016/02/Finanzas-para-la-Sostenibilidad.pdf

MINAM (2016c), Areas Naturales Protegidas del Perú (2011-2015): Conservación para el desarrollo sostenible, Ministry of Environment, Lima

MINAM (2016d), MINAM y aliados destacan y recompensan a comunidades campesinas por preservar la variabilidad de la quinua nativa en Puno, Press release 12 May, Ministry of Environment, Lima, www.minam.gob.pe/notas-de-prensa/minam-y-aliados-destacan-y-recompensan-a-comunidadescampesinas-por-preservar-la-variabilidad-de-la-quinua-nativa-en-puno/

MINAM (2015a), Lineamientos de Política de Inversión Pública en materia de Diversidad Biológica y Servicios Ecosistémicos 2015-2021, Ministerial Resolution No. 199-2015-MINAM, Ministry of Environment, Lima, www.minam.gob.pe/wp-content/uploads/2015/08/RM-N\%C2\%B0-199-2015MINAM1.pdf

MINAM (2015b), Inician acciones para la conservación y uso sostenible de la diversidad de quinua en Puno, Press release, 8 September, Ministry of Environment, Lima, www.minam.gob.pe/notas-deprensa/inician-acciones-para-la-conservacion-y-uso-sostenible-de-la-diversidad-de-quinua-en-puno

MINAM (2015c), La Evaluación Ambiental Estratégica (EAE) es una opción para tomar decisiones sustentables, Press release, 20 August, Ministry of Environment, Lima, www.minam.gob.pe/perunatural/2015/08/20/la-evaluacion-ambiental-estrategica-eae-es-una-opcionpara-tomar-decisiones-sustentables

MINAM (2015d), Peru Business and Biodiversity Initiative - Progress and Achievements in 2015, Ministry of Environment, Lima 
MINAM (2015e), JICA firma acuerdo con MINAM y APCI para dar cooperación técnica en conservación de los bosques y REDD+ en el Perú, 30 September, Ministry of Environment, Lima, www.minam.gob.pe/bosques/2015/09/30/jica-firma-acuerdo-con-minam-y-apci-para-darcooperacion-tecnica-en-conservacion-de-los-bosques-y-redd-en-el-peru

MINAM (2014a), Estrategia Nacional de Biodiversidad Biológica al 2021, Plan de Acción 2014-2018. Ministry of Environment, Lima

MINAM (2014b), Quinto Informe Nacional ante el Convenio sobre la Diversidad Biológica: Perú 20102013, Ministry of Environment, Lima, www.cbd.int/doc/world/pe/pe-nr-05-p1-es.pdf

MINAM (2014c), Informe Nacional del Estado del Ambiente 2012-2013, Dirección General de Políticas, Normas e Instrumentos de Gestión Ambiental, Ministry of Environment, Lima

MINAM (2012), Informe Nacional del Estado del Ambiente 2009-2011, Ministry of Environment, Lima

MINAM (2011a), Readiness Preparation Proposal of Peru, Submitted to the Forest Carbon Partnership Facility, 7 March, Ministry of Environment, Lima

MINAM (2011b), El Perú de los bosques, Ministry of Environment, Lima

MINAM (2011c), Plan Nacional de Acción Ambiental, Ministry of Environment, Lima

MINAM (2009), Reglamento interno de la Comisión Nacional de Diversidad Biológica, Ministry of Environment, Lima

Multi-Sector Commission (2012), “Strategic Axes of Environmental Management”, www.minam.gob.pe/wp-content/uploads/2013/06/EJES-ESTRATEGICOS-DE-LA-GESTIONAMBIENTAL.pdf

OECD (2018, forthcoming), Mainstreaming Biodiversity for Sustainable Development, OECD Publishing, Paris

OECD/ECLAC (2017), OECD Environmental Performance Reviews: Peru 2017, OECD Publishing, Paris, dx.doi.org/10.1787/9789264283138-en

OECD (2016a), Multi-dimensional Review of Peru: Volume 2. In-depth Analysis and Recommendations, OECD Development Pathways, OECD Publishing, Paris, dx.doi.org/10.1787/9789264264670-en.

OECD (2016b), OECD Public Governance Reviews: Peru: Integrated Governance for Inclusive Growth, OECD Publishing, Paris, dx.doi.org/10.1787/9789264265172-en

OECD (2016c), OECD Territorial Reviews: Peru 2016, OECD Publishing, Paris, dx.doi.org/10.1787/9789264262904-en

OECD (2015), Multi-dimensional Review of Peru: Volume I. Initial Assessment, OECD Development Pathways, OECD Publishing, Paris, $\underline{\text { dx.doi.org/10.1787/9789264243279-en }}$ 
Orihuela, J.C. and M. Paredes (2017), Fragmented Layering: Building a Green State for Mining in Peru, in Dargent, E., Orihuela, J.C., Paredes, M. and Ulfe, M.E. (eds.) Resource Booms and Institutional Pathways: The Case of Peru. New York City: Palgrave

Oxford Business Group (2016), The Report 2016: Peru, www.oxfordbusinessgroup.com/peru-2016

PAGE (2017), Documento Resumen - Perú: Crecimiento Verde. Análisis cuantitativo de políticas verdes en sectores seleccionados de la economía

PAGE (2015), Perú crecimiento verde: análisis de la economía peruana. Condiciones favorables y oportunidades

Piu, H.C. and M. Menton (2014), The context of REDD+ in Peru: Drivers, agents and institutions. Occasional Paper 106. Bogor, Indonesia: CIFOR

Potts, J. et al. (2016), State of Sustainability Initiatives Review: Standards and the Blue Economy, International Institute for Sustainable Development

Proambiente (2016a), “Se aprobó primer proyecto “verde” en el Perú”, 10 February, www.proambiente.org.pe/noticia nota.php?id=101\&aid=0 \&pagina $=1$

Proambiente (2016b), "Fortalecimiento de la innovación y competitividad del Biocomercio”, PerúBioInnova, www.proambiente.org.pe/umwelt/recursos/publicaciones/Factsheet\%20PeruBioInnova.pdf

PRODERN (2018), “Ejo temático: Gestión y conservación de la biodiversidad”, Proyecto Desarrollo Estratégico de los Recursos Naturales, http://prodern.minam.gob.pe (accessed 22 April 2018)

PRODUCE (2014), Plan Nacional de Diversificación Productiva: Nuevos Motores para el Desarrollo del País, Ministry of Production, Lima

PROMPERU (2014), Biocomercio: modelo de negocio sostenible, Exports and Tourism Promotion Board of Peru, Lima

Rénique, G. (2009) "Law of the Jungle in Peru: Indigenous Amazonian uprising against neoliberalism”, Socialism and Democracy, Vol. 23/3, Taylor \& Francis, pp. 117-135, doi.org/10.1080/08854300903290835

Rodriguez-Ferrand, G. (2011), "Peru: New law granting right of consultation to indigenous peoples”, Global Legal Monitor, 27 September 2011, Library of Congress, Washington, DC, www.loc.gov/law/foreign-news/article/peru-new-law-granting-right-of-consultation-to-indigenouspeoples

RSPO (2017), Case Tracker: Plantaciones de Pucallpa, www.rspo.org/members/complaints/status-ofcomplaints/view/88

SDC (2018), Bilateral relations Switzerland-Peru, Swiss Development Co-operation website, www.eda.admin.ch/eda/en/home/representations-and-travel-advice/peru/switzerland-peru.html (accessed 3 June 2018) 
SPDA (2012), La realidad de la minería ilegal en países amazónicos, Peruvian Society for Environmental Law, Lima

Swenson, J. J. et al. (2011), Gold mining in the Peruvian Amazon: global prices, deforestation, and mercury imports, PloS one 6(4):e18875, doi.org/10.1371/journal.pone.0018875

Thompson, I.D. et al. (2011), Forest biodiversity and the delivery of ecosystem goods and services: translating science into policy, BioScience, 61: 972-981, doi.org/10.1525/bio.2011.61.12.7

Trujillo, M. (2014), Análisis de progresos en la certificación forestal fsc, restricciones y desafíos en concesiones forestales de la amazonia peruana, Proambiente/GIZ, Lima

Tveteras, S., C. E. Paredes and J. Peña-Torres (2011), “Individual Vessel Quotas in Peru: Stopping the Race for Anchovies”, Marine Resource Economics, 26 (3): 225-232

UNDP Peru (2016), Perú reconoce la biodiversidad y los ecosistemas como activos para el desarrollo, 27 June, www.pe.undp.org/content/peru/es/home/presscenter/articles/2016/06/27/per-reconoce-labiodiversidad-y-los-ecosistemas-como-activos-para-el-desarrollo/

UNHRC (2014), Report of the Special Rapporteur on the rights of indigenous peoples, Addendum: The situation of indigenous peoples' rights in Peru with regard to the extractive industries, 3 July, A/HRC/27/52/Add.3, www.refworld.org/docid/53eb3c774.html (accessed 27 June 2018)

UNODC (2017), Perú: Monitoreo de cultivos de coca 2016, United Nations Office on Drugs and Crime, Vienna

UNODC (2016), Perú: Monitoreo de cultivos de coca 2015, United Nations Office on Drugs and Crime, Vienna

USAID (2016a), Initiative for Conservation in the Andean Amazon ICAA-WIDE Final Report, March

USAID (2016b), Biodiversity How-To Guide 1, 2 and 3, USAID, Washington, DC, usaidlearninglab.org/library/usaid-biodiversity-programming-how-guides

USAID (2015a), Toward Zero-Deforestation Oil Palm in Peru: Understanding Actors, Markets, and Barriers, Forest Carbon, Markets and Communities (FCMC) Program, March

USAID (2015b), Biodiversity and Development Handbook, USAID, Washington, DC

USAID (2015c), Biodiversity and Development Research Agenda, USAID, Washington, DC

USAID (2014a), Enhancing forestry governance in the Peruvian amazon: Mid Term Evaluation of Peru Forest Sector Initiative, (PFSI) - AID-527-T-11-00001, April

USAID (2014b), USAID Biodiversity Policy, USAID, Washington, DC

USAID (2013), “SCAPES Landscape Profile: The Greater Madidi-Tambopata Landscape”, www.rmportal.net/biodiversityconservation-gateway/resources/projects/scapes-1/scapes-landscapeprofile-the-greater-madidi-tambopata-landscape/view 
USAID (2012), “USAID/Peru Country Development Cooperation Strategy”, Lima, Peru: USAID/Peru, www.usaid.gov/sites/default/files/documents/1862/PeruCDCS_0.pdf

USDA (2017), Peruvian Coffee Production Bouncing Back, Annual Report, USDA, Washington, DC

Walton, B. (2016), Conga Mine in Peru Halted by Water Concerns, Civic Opposition, Circle of Blue, April, www.circleofblue.org/2016/south-america/conga-mine-peru-halted-water-concerns-civicopposition

Wieland Fernandini, P. and R.F. Sousa (2015), "The distribution of powers and responsibilities affecting forests, land use, and REDD+ across levels and sectors in Peru: A legal study”, Occasional Paper 129, CIFOR, Bogor, Indonesia

World Bank (2017a), Peru country webpage, www.data.worldbank.org/country/peru (accessed 30 January 2017)

World Bank (2017b), Gini Index, www.data.worldbank.org/indicator/SI.POV.GINI (accessed 31 January 2017),

World Bank (2016), "Implementation, completion and results report on programmatic loans in the amount of US\$455 million to the Republic of Peru for the first, second, and third environmental development policy loans”, 30 September, Report No: ICR00001921

World Bank (2007), Republic of Peru. Environmental Sustainability: A Key to Poverty Reduction in Peru. Country Environmental Analysis, World Bank, Washington, DC

WWF (2014), "Peruvian Government takes first steps towards responsible procurement of wood products", 13 November, WWF, www.wwf.org.pe/en/?233073/peruviangovernmenttakesfirststepstowardsresponsibleprocurementofwo odproducts

Young, J. and Lankester, K. (2013), “Peruvian Anchoveta Northern-Central Stock Individual Vessel Quota Program”, Environmental Defence Fund 


\section{Annex}

\section{OECD Rio marker methodology captures mainstreaming within development activities}

Since 1998, the OECD Development Assistance Committee (DAC) has monitored development finance targeting the objectives of the Rio Conventions through DAC members' reporting using the Rio marker methodology. There are four Rio markers: biodiversity, climate change mitigation, climate change adaptation and desertification.

The Rio markers aim to capture the mainstreaming component of biodiversity and other environmental objectives across development co-operation. Every development cooperation activity reported to the OECD DAC Creditor Reporting System (CRS) should be screened and marked, whether it is targeting the objectives of the Convention on Biological Diversity (CBD), using the score 'principal', 'significant' or 'not targeted'. Activities scored 'principal' would not have been funded but for their biodiversity objective. Activities scored 'significant' have a primary objective other than biodiversity, but have been formulated or adjusted to help meet biodiversity concerns. Biodiversity is essentially mainstreamed into these activities, being targeted as a secondary objective.

\section{Definition and Criteria for Eligibility}

Biodiversity-related development finance is defined as activities that promote at least one of the three objectives of the CBD: the conservation of biodiversity, sustainable use of its components (ecosystems, species or genetic resources), or fair and equitable sharing of the benefits of the utilisation of genetic resources.

An activity can be marked with the biodiversity Rio marker, if it contributes to:

a. protection of or enhancing ecosystems, species or genetic resources through in-situ or ex-situ conservation, or remedying existing environmental damage; or

b. integration of biodiversity and ecosystem services concerns within recipient countries' development objectives and economic decision making, through institution building, capacity development, strengthening the regulatory and policy framework, or research; or

c. developing countries' efforts to meet their obligations under the Convention. 


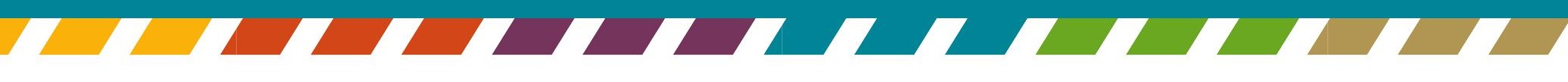

